\title{
Aids é coisa séria! - humor e saúde: análise dos cartuns inscritos na I Bienal Internacional de Humor, 1997
}

\section{Get serious about Aids! - humor and health: overviewing the cartoons on the I Bienal Internacional de Humor, 1997}

\author{
Caco Xavier \\ Jornalista, cartunista e editor do programa Radis \\ Fundação Oswaldo Cruz \\ caco@ensp.fiocruz.br \\ caco@pobox.com
}

\begin{abstract}
A partir de análise baseada na semiótica de Peirce de um extenso corpus formado por cartuns sobre a Aids, discute-se a relação entre o riso e a coisa trágica. Tal análise pressupõe a conceituação do cartum como discurso gráfico e a conseqüente delimitação de seu modo de ser, centrado na necessidade do fazer-rir. O cartum sobre Aids propicia, ainda, a definição das atividades e intenções do cartunista e, de modo indireto, uma visão geral acerca do imaginário social sobre a doença Finalmente, o estudo aprofunda a discussão sobre o riso e o humor como ferramentas de comunicação ou pedagógicas.

PALAVRAS-CHAVE: humor, riso, cartum, riso trágico, Aids, semiótica.
\end{abstract}

This work intends to discuss the relation between laughter and tragedy by means of an analysis based on the Peircean semiology of a comprehensive collection of cartoons about Aids. This analysis assumes the conception of cartoon as a graphic speech and its inherent delimitations, focusing on the necessity of making laugh. The cartoon about Aids also provides the definition of the cartoonist's activities and intentions and, indirectly, provides an overview of the social imaginary of the disease. At last, the study deepens on the subject of laughter and humor as communicative or pedagogical means.

KEYWORDS: humor, laughter, cartoon, tragic laughter, Aids, semiology.

U

ma bolota cai ao acaso na cabeça de um proto-homem, placidamente deitado sobre um galho de árvore. Alguns outros da mesma espécie, que estão próximos, espantam-se com o inusitado do acontecimento e subitamente emitem sons decorrentes da contração quase involuntária do diafragma. Riem. Esta cena, magistralmente reproduzida por JeanJacques Annaud em seu filme A guerra do fogo, representa o momento em que o homem aprende a rir. Para que o riso exista, é preciso que exista também um cérebro apto a produzir e reter esquemas mentais, a conhecer. Para que o riso exista, é necessário que haja um cogito, a compreensão do eu e do outro, do que seja um comportamento 'padrão' e esperado e, por fim, é preciso que exista também a distinção entre esse momento 'padrão' e o insuspeito e súbito acaso, que rompe com ele. 
Em 1997, parceria formada entre a Estação das Artes, Jal \& Gual Comunicação e a Central Geral dos Trabalhadores (CGT) organizou, em São Paulo, a Bienal Internacional de Humor Sem Aids, Com Amor. Esta bienal, cujo tema foi a prevenção da Aids, contou com exposição de cartunistas convidados e mais um concurso de cartuns, aberto a profissionais e amadores, brasileiros e estrangeiros. $\mathrm{O}$ concurso recebeu grande volume de inscrições, e dos quase três mil cartuns inscritos (de 47 países e da quase totalidade dos estados brasileiros), 180 foram selecionados para o catálogo e exposição principal.

A análise desse material, restrito ao tema da prevenção da Aids, permite a contemplação conjunta de quatro processos:

1) Estudo dos mecanismos do riso e do humor, partindo da vasta produção teórica sobre o assunto, aqui utilizada sendo focada num objeto específico, o cartum.

2) Elaboração de uma metodologia de análise do cartum, cuja literatura é escassa e pontuada de lacunas.

3) Percepção do trágico, do riso trágico, e a tentativa de compreensão de um aparente paradoxo: por que e para que rimos do que se chama comumente de 'tragédia'?

4) Significação social da pandemia da Aids. Através da obra dos cartunistas, podemos vislumbrar em determinada medida o imaginário social acerca da doença e suas inumeráveis implicações em nossa sociedade.

\section{Humor e 'humores', riso e ridículo}

A medicina romana dos tempos de Galeno estipulava que o organismo humano era regido por quatro elementos líquidos que circulam pelo corpo, chamados humores: o sangue, a fleuma, a bile amarela e a bile negra, sendo que a predominância de um deles definiria uma pessoa de caráter sangüíneo, fleumático, melancólico ou colérico, respectivamente. Quem tivesse os quatro humores em equilibrio seria uma pessoa bem-humorada. Vem daí a concepção de humor, e também a grande confusão semântica que se formou posteriormente. Hoje, esta palavra tem basicamente dois sentidos: um vinculado à alegria, ao clássico 'equilíbrio dos humores', à sensação de satisfação e à cordialidade; e outro vinculado ao riso e ao risível. É a diferença entre o bem-humorado e o humorista, o que ri e o que faz rir.

Foi Aristóteles (1956), porém, quem deu a partida para a formulação de uma filosofia do riso quando, em As partes dos animais, disse que "o homem é o único animal que ri" ("e é rindo que ele mostra o animal que é", ajuntaria Millôr Fernandes, séculos mais tarde). Embora sem haver formulado uma 'teoria da comédia', o Estarigita levantou alguns pontos importantes em sua Poética, definindo o cômico como a negação do trágico, ao mesmo tempo em que notava que o emprego abusivo e absurdo das metáforas terminariam por produzir efeitos cômicos.

Mas o que realmente importa saber acerca do pensamento da época a respeito do riso é que quase todo ele é elaborado em função das relações e processos físicos do ato de rir, envolvendo calor, cócegas, respiração e diafragma. "O pensamento se põe em movimento contra a vontade”, diz Aristóteles (1987). Caso tenha existido realmente o afamado Segundo livro da poética, inteiramente dedicado à comédia - lenda corrente nos meios acadêmicos e motivo principal das buscas dos personagens do romance O nome da rosa, de Umberto Eco (1983) -, talvez tivéssemos hoje um panorama mais definido do pensamento enciclopédico de Aristóteles a esse respeito. $\mathrm{O}$ pesquisador alemão Manfred Fuhrmann chega a sugerir que, no livro perdido, seja atribuído ao acaso, na comédia, a mesma função que o destino teria na 
tragédia (Alberti, 1999, p. 54), conceito que ao mesmo tempo se enquadra na concepção aristotélica do cômico como o não-trágico e ainda teria eco nas mais recentes elaborações sobre o tema.

A Idade Média trouxe à tona muitas controvérsias e polêmicas sobre o tema, em certa medida contempladas em $\mathrm{O}$ nome da rosa, de Eco, ficção medievalista com requintes de pesquisa científica. Neste trabalho, há a confrontação do pensamento baseado na autoridade teológica, personificado pelo monge Jorge de Burgos, com o pensamento metodológicocientífico de Guilherme de Baskerville. "O Cristo não ri", diz Jorge, acrescentando que o riso deforma o rosto do homem, assemelhando-o ao de um macaco (Eco, 1998, p. 158). Nesta mesma passagem, ao ser refutado por Guilherme, que lembrou-lhe que "macacos também não riem; o riso é próprio do homem, é sinal de sua racionalidade”, o velho monge diz que o riso é sinal de estultície, pois "quem ri não acredita naquilo de que está rindo, mas tampouco o odeia". Adiante, o mesmo religioso assevera: "Eis por que o Cristo não ria: o riso é incentivo à dúvida!" "Mas às vezes é justo duvidar", diz Guilherme, antecipando Descartes. O talento do autor, nesse trabalho, faz com que se conheça num só olhar as contradições existentes no pensamento medieval acerca do risível, como também constrói sentenças paradoxais que terminam por elevar o riso a uma espécie de lâmina, com a qual é possível curar ou matar, dependendo da mão que a empunha. A frase de Jorge ("quem ri... não acredita... tampouco odeia”) é particularmente significativa, e certamente haveremos de voltar a ela no decorrer deste trabalho.

É somente na Renascença que aparece de forma definitiva a razão como elemento necessário à significação do riso, e também a concepção do riso como força criadora, positiva. Embora ainda contaminada pela abordagem physis, a idéia renascentista assegura que o riso legítimo pressupõe o cumprimento de uma atividade cognitiva (Alberti, op. cit., p. 103). Laurent Joubert é o primeiro a dizer que os recém-nascidos e os animais não riem porque lhes falta o pensamento, a "cogitação". A partir daqui temos, naturalmente, a introdução de outro conceito, o do súbito, que atravessa a razão como uma flecha e fere o pensamento lógico, inserindo um outro tipo de pensamento, absurdo e ilógico, cuja instantânea intromissão leva ao riso.

\section{Três categorias do riso}

Para efeitos deste artigo, classifiquei o riso em três categorias, segundo três funções. Esta classificação está restrita à especificidade deste nosso tema já que, certamente, tais funções podem vir a coexistir e atuar simultaneamente em determinadas circunstâncias.

\section{1) Riso criador}

O riso aparece com um caráter ao mesmo tempo negativo (ridicularizando o 'inimigo', ou desmistificando aquilo que é 'sagrado') e positivo (corrigindo um presumível 'defeito', do indivíduo ou da sociedade). O riso tem, aqui, função social, tornando-se mecanismo de ajuste, corregedor, criador. $\mathrm{O}$ principal compilador dessa teoria a respeito do riso é Bergson (1983). A máxima destes atributos poderia ser, certamente, a expressão de Proudhon: "O humor é a verdadeira liberdade"! Porém, talvez o aspecto mais importante do atributo criador do riso seja colocar em oposição o flexível (a vida, o que é natural) e o inflexível (o 'mecanismo', o automático, o antinatural). 


\section{2) Riso iluminador}

Jorge Luis Borges compara o riso aos sábios e paradoxais koans zen-budistas, cuja intenção é propiciar uma iluminação súbita aos discípulos. Kant diz que o riso é conseqüência de uma "impossibilidade cognitiva". Freud relaciona-o aos mecanismos dos sonhos. Bataille fala de um "salto do possível para o impossível". Mas é Deleuze (1998) quem formula com mais espaço a teoria do riso como 'iluminação', ao tratar do paradoxo, do não-senso e do espelho de Alice. Assim, o riso se dá a partir da intromissão de um pensamento de outra ordem lógica, que provoca uma súbita pane em nosso pensamento linear. Essa 'pane' é capaz de levar-nos a um novo pensar. A partir de pensamentos que parecem contraditórios, o riso nos leva a assistir à própria gênese da contradição. $O$ mais importante é que o humor passa a funcionar, aqui, como a subversão do bom senso e do senso comum, ou seja, do dito 'pensamento da normalidade'.

\section{3) Riso destruidor}

"A caricatura é uma arte sagrada”, diz Jean Giraudoux, lembrando que toda caricatura realmente boa deriva da dança macabra, e seu arcabouço é o esqueleto. Generalizando, talvez possamos atribuir ao riso esta definição. A dança macabra, como celebração e pantomima, invadiu a Europa na Idade Média, quando bufões, mascarados, esqueletos e diabos dançavam nos sepulcros, de um cemitério a outro. Chesterton (apud Lima, 1963, p. 49), em conhecido ensaio, dizia que não era o simples terror da morte ou mesmo a abolição desse terror (num tempo em que os homens iam ao encontro da morte cantando) que justificavam tais celebrações, mas sim "a idéia da degradação do homem, na fealdade careteira de sua estrutura". Antes, havia "esperança e glorificação", agora não há mais nada, apenas a morte. Rosset (1989, p. 87), falando a respeito do pensamento trágico, explica que este caracteriza-se justamente pela "impossibilidade de crer que possa haver crença". O acaso, então, passa a ser o mote principal, a constatação da total impossibilidade de controle na natureza e na existência humana, a perdição, a idéia da ausência de toda e qualquer ordem ou referencial. Dessa maneira, o riso nasce quando algo desaparece sem razão. $O$ riso exterminador, ou riso trágico, significa a vitória do caos sobre a aparência da ordem, o reconhecimento do acaso como verdade.

\section{O cartum, o punctum e a seta de Guilherme Tell}

O cartum é uma anedota gráfica, segundo o Dicionário de comunicação de Rabaça e Barbosa (1998). Um cartum clássico compõe-se de um jogo visual de idéias contido numa única ilustração, sem a presença de qualquer texto escrito. No entanto, há cartuns que se utilizam de balões ou legendas, outros que apresentam duas ou mais ilustrações em seqüência. Atualmente há tolerância em relação à utilização de imagens em seqüência, desde que ilustrando uma única 'piada', que possa ser apreendida de uma só vez e em espaço delimitado (uma mesma folha, no máximo). A principal diferença entre um cartum e uma charge é que enquanto o primeiro se utiliza de idéias gerais, universais e atemporais para realizar seu 'trocadilho visual', a segunda está sempre fundamentada num fato e momento históricos e objetivos, como, por exemplo, um acontecimento político.

Ao contrário da quantidade de estudos acerca do humor, da comédia e do riso, não há literatura abrangente e significativa sobre o cartum, representação gráfica do cômico. Foi necessário estabelecer, portanto, critérios específicos para a construção de uma metodologia 
de análise. O ponto de partida foi considerar o cartum como dotado de linguagem própria, cujos aspectos sintáticos, semânticos e pragmáticos não poderiam ser meramente 'importados' da linguagem verbal e escrita. Para a compreensão deste 'texto' gráfico essencialmente pictórico, optei como fundamento pelos parâmetros e classificações da semiótica de Peirce, capazes de prover critérios e pontos de abordagem acerca de qualquer linguagem ou processo cognitivo.

Segundo a classificação dos signos de Peirce (1995), um cartum é um argumento, um "legissigno", constituindo uma "estrutura narrativa e argumentativa complexa" (Santaella e Nöth, 1997). As imagens tornam-se símbolos quando o significado de seus elementos, para ser compreendido, necessita da ajuda do código de uma convenção cultural. $O$ cartum encaixa-se nessa modalidade, onde o veículo do signo (primeiridade) e objeto (secundidade) necessitam de um terceiro, a convenção aprendida a priori (terceiridade) para que signifique.

Então vemos que:

a) por se tratar de um argumento, o cartum deve ser encarado como leitura fechada em si mesma, cada cartum encerrando em si seu próprio discurso (ainda que não esteja, obviamente, dissociado de um contexto social e cultural);

b) por possuir linguagem própria e analógica, a compreensão de seus códigos deve ser efetuada a partir de sua especificidade, não em decorrência da comparação direta com outras linguagens.

Para contemplar a propriedade do riso no cartum (qualidade e atributo fundamental deste), tomei de empréstimo conceitos estabelecidos por Roland Barthes (1984) na análise de corpus de imagens fotográficas. Para Barthes, toda imagem individual contém um studium, que é o cenário, o equilíbrio da composição, a intenção do autor, a combinação e associação dos diversos elementos em cena. Para efeitos deste artigo, chamo studium o cartum como um todo, a cena, a composição geral dos elementos: traço, texto, cor, idéia.

Analisando imagens fotográficas, Barthes repara que por vezes acontece de certo detalhe causar uma pungência, uma 'ferida' no espectador. A esse detalhe Barthes nomeou punctum, palavra latina que significa 'picada, ferida'. Punctum é aquilo que fere, chama atenção, que diferencia fundamentalmente uma foto de tantas outras, que punge, atinge. A maioria das imagens fotográficas que vemos (Barthes assegura) não contém punctum algum, porque nem sempre há na foto esta 'intenção de ferir'. No entanto (aqui está a razão principal pela qual decidi 'assumir' tais conceitos barthianos), esta é a intenção primordial de um cartum! Um cartum sempre há de ter o seu punctum, sua flecha, sua ferida. Barthes considera o punctum como "um estalo, que provoca um pequeno abalo, a passagem de um vazio" numa impressionante correspondência com as definições do riso apresentadas por Deleuze. Este punctum está associado à deflagração do riso. Há casos, porém, em que o punctum está ausente do cartum, e então temos aqui a constrangedora situação da 'piada sem graça'. Cartum sem ferida, sem riso, sem punctum, é meramente studium, uma ilustração comum. Para efeitos desse trabalho e na análise dos cartuns da bienal, embora pudéssemos considerar como 'não-cartum' este 'cartum sem punctum', preferi assumir a intenção do autor em criar um cartum, mesmo que não tenha obtido êxito. Esta posição baseia-se ainda no fato inegável de que achar graça ou não de um cartum é um dado extremamente subjetivo.

A conhecida lenda de Guilherme Tell é um bom diagrama do fazer-e-ler cartum. Imaginemos: o arqueiro e seu arco tensionado, com a flecha armada; no outro lado, um rapaz equilibrando delicada maçã sobre a cabeça. Imaginemos ainda que a maçã não está sobre a cabeça do rapaz, mas dentro dela. $\mathrm{O}$ arqueiro dispara a flecha. $\mathrm{O}$ processo da leitura do cartum é toda 
esta cena, dinâmica e súbita. $\mathrm{O}$ arqueiro é o autor do cartum. $\mathrm{O}$ arco tensionado é o studium, a cena. A flecha é o punctum, mecanismo do riso, aquilo que vai 'ferir'. O homem com a maçã é o leitor, e a maçã é seu pensamento lógico. A flecha-punctum atravessa a mente do leitor despedaçando a maçã, ferindo assim o cogito, atingindo subitamente sua razão linear. Nesse exato instante em que a flecha atinge seu alvo, o rapaz, justificadamente, ri.

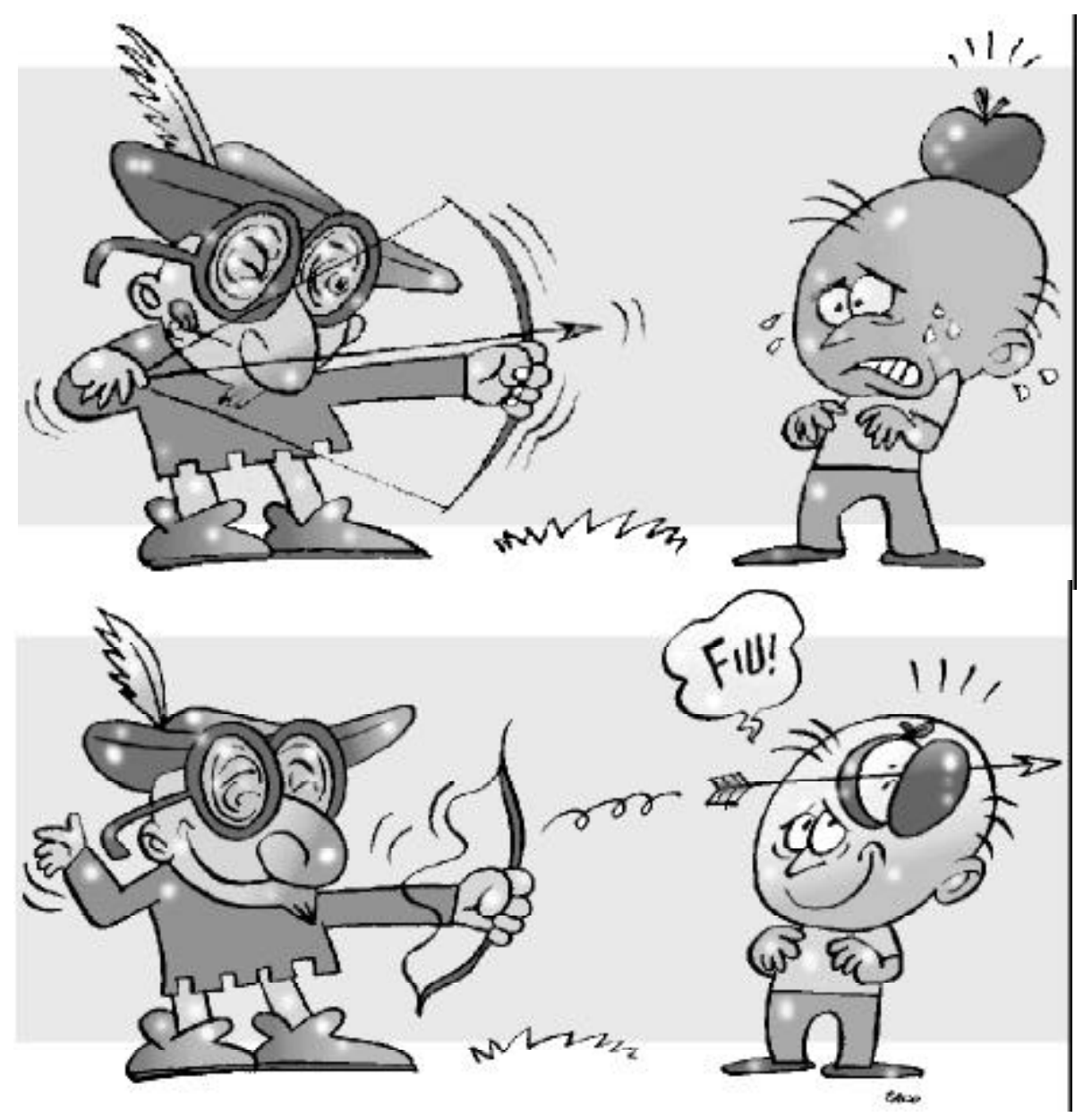

Caco Xavier (Rio de Janeiro - Brasil)

\section{As três faces do cartunista}

O fazer-cartum é uma arte que depende de identificação imediata, portanto o cartunista é obrigado a laborar essencialmente sobre referências sociais e comuns visando a atingi-la. É uma 'arte de superfície' (e a superfície é o que há de mais profundo, segundo Deleuze). Tal identificação é, na maioria das vezes, plenamente conquistada, o que nos leva à identificação de pelo menos três funções do artista. O cartunista é, em determinada medida:

a) Voz crítica da sociedade, um minúsculo Grilo Falante, seguindo atrás dela sussurrando (às vezes bradando histericamente) acerca da verdade. O Grilo Falante faz parte da mesma sociedade à qual 'cri-critica'. A questão que se levanta aqui é: O que é essa 'verdade'? Quem a 'revelou' ao artista? É uma verdade absoluta ou contingente? Não nos importa agora tentar 
responder a isso. Importa saber que há uma 'verdade' (contingente ou absoluta, oriunda sabese lá de onde) e que esta é sussurrada pelo artista aos ouvidos da sociedade.

b) $\mathrm{O}$ herói Perseu, que usa o espelho (o cartum) para revelar à Medusa seu próprio rosto horrendo, única maneira de derrotar o poder das serpentes que brotam de sua cabeça. Aqui, o artista está momentaneamente 'fora' da cena, figurando a 'insensibilidade' que Bergson destaca como imprescindível ao exercício do humor. Ele simplesmente 'reflete' à sociedade aquilo que ela é e possui, mas que dificilmente reconhece.

c) 'Antena da raça', expressão utilizada por Ezra Pound para definir certa qualidade de artistas. Para Pound, o verdadeiro artista é capaz de reconhecer e 'captar' antes de todos uma tendência futura, a direção para qual a sociedade caminha, antes de esta estar definitivamente estabelecida.

Como o cartum depende do riso (certeza do alvo atingido) para que alcance seu objetivo primordial, a visão do cartunista e a visão da sociedade têm estrita relação. $O$ trabalho do cartunista reflete, portanto, em determinada medida, um imaginário social, tem como matériaprima o senso-comum. Será que há sempre uma intenção, por parte do artista, de modificar comportamentos ou promover a reflexão? Não necessariamente e não majoritariamente. Constato, pela análise dos cartuns selecionados, que na maioria das vezes o artista toma para si a 'função do espelho', atirando ao rosto da Medusa seu próprio reflexo, em detrimento de arvorar-se em 'grilo falante' ou, menos ainda, 'antena da raça'.

\section{Corpus, metodologia}

Num primeiro momento, 2.925 cartuns foram classificados e $813(27,8 \%)$ destes analisados mais a fundo. Optei por respeitar as classificações primárias estabelecidas pelos organizadores, portanto todas as tabelas criadas e utilizadas repetem-se em três grupos de cartuns:

Grupo I - Artistas convidados: 65 trabalhos de autores renomados, 53 de autores nacionais (nove estados brasileiros) e 12 de autores internacionais (seis países).

Grupo II - Selecionados: 180 trabalhos, avaliados e selecionados pela comissão julgadora do concurso. A maioria desses trabalhos foi executada por artistas profissionais. Destes 180 trabalhos, noventa são nacionais (de 14 estados brasileiros), 89 internacionais (de 37 países) e um resultado de parceria entre um autor nacional e um internacional.

Grupo III - Inscritos mas não selecionados: demais cartuns inscritos. A soma dos três grupos fornece a totalidade de cartuns inscritos. Neste grupo de não selecionados há um sub-grupo especial, denominado repescagem (denominação atribuída pela própria organização do evento), do qual fazem parte cartuns escolhidos a partir de uma segunda seleção, realizada pela própria organização em momento posterior ao julgamento do concurso, visando incluir mais trabalhos de bom nível para compor a exposição principal: 55 trabalhos, sendo quarenta nacionais (de dez estados brasileiros) e 15 internacionais (de 12 países).

Todo cartum que conste dos grupos I e II e ainda do subgrupo repescagem e mais todo material internacional foi objeto de acurada análise, e os dados deste levantamento foram cruzados e combinados. O total de 813 cartuns analisados estava assim dividido: 612 internacionais - Romênia (64 cartuns), Irã (45), Ucrânia (45), Iugoslávia (43) e China (42) tiveram as maiores participações; duzentos nacionais, de 18 estados brasileiros - São Paulo (98 cartuns) foi o estado responsável por praticamente a metade da participação brasileira; e um cartum decorrente de uma parceria entre um autor nacional (RJ) e um internacional 
(França). A quantidade de participação (de países e estados brasileiros) se deve mais à divulgação do evento, abrangente mas desigual, em virtude de óbvias limitações financeiras, e não propriamente devido à produção ou quantidade de artistas existentes nas localidades. Por essa razão não insisti em avaliar uma possível relação entre quantidade de cartuns inscritos e produção. A análise dos cartuns propiciou várias conclusões preliminares, sendo que as principais delas estão descritas mais adiante.

A decisão de privilegiar, num primeiro momento, os dados resultantes do levantamento sobre as três categorias mencionadas deveu-se ao fato de que tais cartuns foram alvo de rigoroso juízo, realizado por um corpo de jurados de reconhecida competência na área, que os aprovou dentre a totalidade dos trabalhos, a partir de critérios que contemplavam não só a estética e as particularidades da linguagem do cartum, mas também o respeito ao tema proposto. Ou seja, tais cartuns são, tanto esteticamente, tanto no tocante ao riso, tanto com relação à abordagem do tema, os mais representativos.

Além da exposição, foram criadas peças gráficas para apoio ao evento: a) um livreto sobre a Aids ( $\mathrm{O}$ que é, quando se pega, onde se pega, como se evita) para municiar os autores candidatos a respeito do tema em questão; b) o regulamento do concurso, contendo mais informações sobre a doença, uma pequena história do humor gráfico brasileiro, depoimentos de pessoas célebres a respeito do humor e saúde, e o regulamento em si. Estas peças foram distribuídas por ocasião do lançamento do concurso, enquanto duas outras peças foram lançadas depois do evento; c) o catálogo da exposição, contendo quarenta cartuns da Exposição dos Convidados e os 180 cartuns selecionados; d) pôster com alguns dos cartuns da Exposição dos Convidados.

\section{Metodologia}

Minha primeira preocupação, na análise desse corpus, foi criar condições para avaliações futuras e cruzamento de informações baseando-me somente nos dados colhidos, sem necessidade de consulta constante aos cartuns. Assim, foram criadas quatro grandes tabelas para entrada de dados. Cada tabela tem várias subdivisões, visando comportar a maior quantidade possível de informações sobre cada cartum, seja quanto à forma, técnica de execução e mecanismos de riso, seja quanto à temática escolhida, signos utilizados ou representações simbólicas.

Numa primeira tabela, há a informação sobre a origem dos trabalhos, se do Brasil (estado) ou exterior (país). A segunda diz respeito à forma dos cartuns. Classifica o tipo de desenho (realista, estilizado, humorístico, misto); uso do texto (mudo, balão, legendas, onomatopéias); uso da cor (preto-e-branco, preto-e-branco mais cor incidental, colorido); técnica de execução (nanquim, guache, aquarela, pastel, lápis, colagem digital, misto) e mecanismo de riso. A terceira tabela distribui em classes e grupos a temática da Aids, destacando-se sexo (homem/ mulher, homem/homem, mulher/mulher, grupo, masturbação); práticas específicas: $\mathrm{F}$ (felação), C (cunilíngua), A (anal) e SM (sadomasoquismo); relações específicas: casamento, infidelidade, prostituição masculina, feminina; sangue (transfusão, tatuagem, acidente profissional, drogas, mãe/filho); social (soropositivo, solidariedade, discriminação); políticas (esfera pública, privada, pesquisa, medicamentos). A última tabela destaca símbolos relacionados com a Aids: sexo e amor (representação da camisinha, da Aids, pênis, vagina, nádegas; coração, cupido/anjo, anel/aliança); Aids como monstro, vírus, morte, diabo, palavra; outros signos (globo, mapa do Brasil, cruz vermelha, morte, cruz/crucifixo, sinais de trânsito, ampulheta, relógio, latrina, outros); antropomorfismo (camisinha, animais); signos referenciais (fatos e figuras públicas, 
tais como Einstein, papa, Lampião, Vênus de Milo, Pensador, Marilyn Monroe); signos referenciais da mitologia, encarnando, por exemplo, Branca de Neve, Batman e Robin, Arca de Noé, Adão e Eva, Vampiro, Pinóquio, Chapeuzinho Vermelho, Saci-Pererê, Tarzan, náufragos, circo - palhaços, equilibristas, trapezistas, mágicos - Rapunzel, A Criação do Mundo, de Michelangelo, Monalisa, o elefante e a formiguinha etc.).

Importante decisão foi tomada para que se determinasse com eficácia o 'mecanismo' utilizado na deflagração do riso. Mesmo esta expressão, mecanismo, não é totalmente adequada, porque sugere algo mecânico, uma 'receita' para o acontecimento do riso. Embora inadequada, a palavra deve ser vista, então, como a tentativa de delimitar o processo 'lingüístico' escolhido pelo autor e utilizado no cartum, que é determinante para que o riso seja deflagrado. Enquanto todas as informações colhidas relacionam-se primariamente com o studium, este é o único campo das tabelas referindo-se estritamente ao punctum. A solução escolhida foi adotar da lingüística algumas figuras de linguagem. Para efeitos da 'anedota gráfica', seis figuras são suficientes para esta classificação. Todo e qualquer punctum está enquadrado predominantemente numa dessas seis figuras:

a) Metáfora: uma coisa posta em lugar de outra.

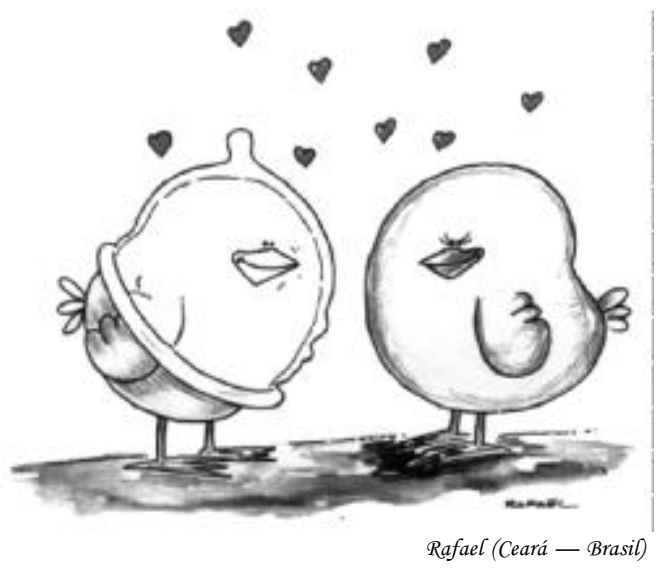

b) Hipérbole: uma coisa ou situação apresentada de forma exagerada.

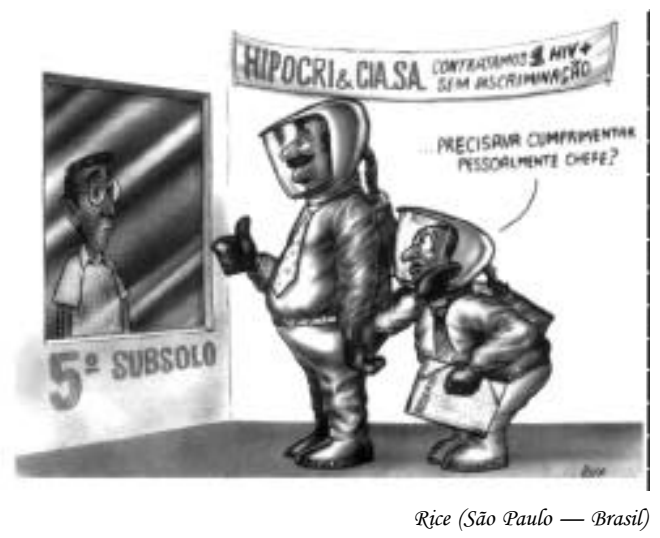


c) Paradoxo: encontro de duas idéias antagônicas e inconciliáveis.

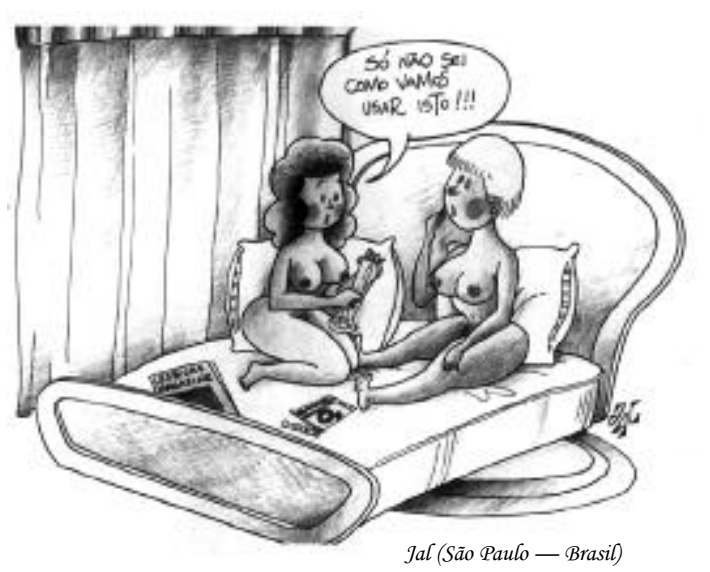

d) Ironia: uma coisa significando idéia contrária ao que usualmente significaria.

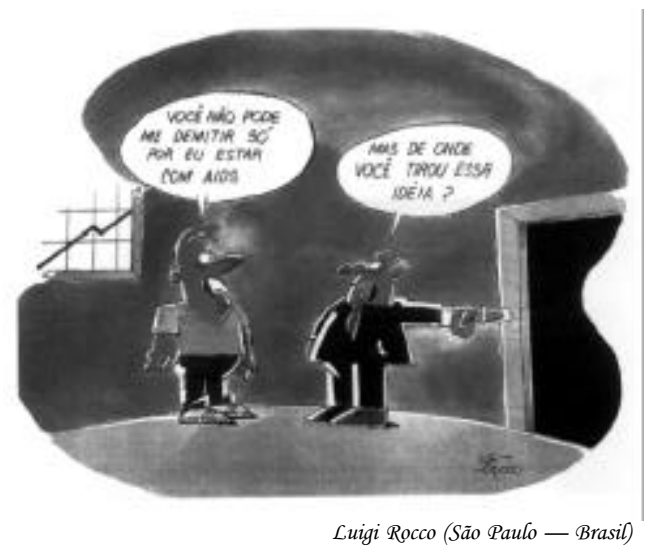

e) Comparação: duas coisas ou situações similares ocupando o mesmo espaço.

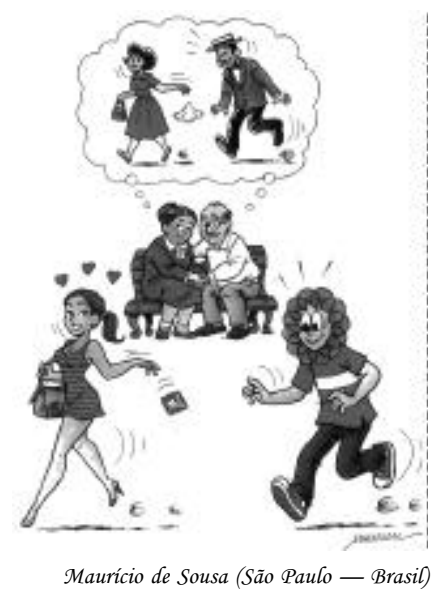

f) Metalinguagem: o cartum tem como tema a si mesmo, seu próprio processo de realização. 
Há ainda uma sétima categoria, caracterizada pela ausência de qualquer uma dessas figuras, o que configura ausência do punctum, um cartum 'sem graça'.

\section{Imaginário social, algumas conclusões}

Estas conclusões estão fortemente baseadas na já referida leitura do cartum como um argumento, onde as representações simbólicas e combinações dos elementos gráficos venham ocupar, em nosso sistema cognitivo, um espaço semiótico e formal, no dizer de Pierre Levy (1998, p. 87), em contraposição ao espaço sensório-motor. O reconhecimento deste quase adormecido 'espaço de semiose', exaustivamente descrito e comentado também por Umberto Eco (1998, p. 134) é fundamental para a validade destas principais conclusões, já que, em determinada medida, são elas abduzidas ${ }^{1}$ em razão de significadores comuns.

O reconhecimento, ainda, de 'tipos cognitivos' comuns à cultura ocidental (não me refiro aqui aos chamados 'primitivos semiósicos', cujos padrões estão além de qualquer cultura específica) é de grande importância para que cartuns de vários continentes e estados brasileiros possam ser coerentemente analisados 'em um só caldeirão' e para que neles sejam identificadas algumas idéias gerais acerca principalmente da Aids e da sexualidade. A reconstrução de tais tipos cognitivos sociais é realizada através da leitura e combinação dos diversos signos usados pelos cartunistas para representar coisas e situações referentes ao tema.

\section{Abordagem temática}

Dos cartuns analisados, 92,2\% tiveram a transmissão da Aids por via sexual como tema principal e, destes, alta porcentagem enfocou exclusivamente o relacionamento homem/ mulher (62\%). Houve alta incidência de cartuns enfocando relações de casamento/infidelidade.

Poucos trabalhos, portanto, referiam-se a outras formas de transmissão $(4,2 \%)$, e menos ainda a aspectos sociais da doença, (discriminação, solidariedade) (2,5\%) ou a políticas e pesquisa $(1,1 \%)$.
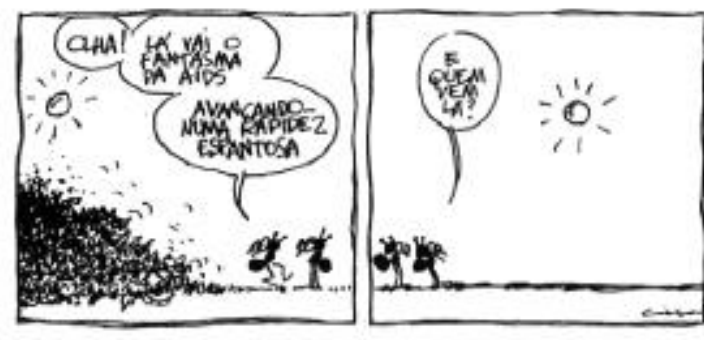

\section{Camisinfa, amor e proteção}

A imagem da camisinha (desenho, palavra escrita ou representação simbólica) está presente em $66,6 \%$ dos cartuns estudados. Numa primeira análise, vemos que a camisinha atua como signo mais de proteção do que propriamente de prevenção. Na maioria das vezes, ela aparece

\footnotetext{
${ }^{1}$ A palavra diz respeito a uma forma de raciocínio e investigação descrita por Peirce (1995): "Abdução é o processo de formação
de uma hipótese explanatória. É a única operação lógica que sugere uma idéia nova, pois a indução nada faz além de determinar

${ }^{1}$ A palavra diz respeito a uma forma de raciocínio e investigação descrita por Peirce (1995): "Abdução é o processo de formação
de uma hipótese explanatória. É a única operação lógica que sugere uma idéia nova, pois a indução nada faz além de determinar um valor, e a dedução meramente desenvolve as conseqüências necessárias de uma hipótese pura."
} 
tão-somente como desenho representando de forma icônica seu objeto. Parodiando Freud, poderíamos dizer que "há momentos, senhores, em que uma camisinha é apenas uma camisinha”. Mas é a partir do momento em que a camisinha é representada simbolicamente que extraímos análises mais significativas. Ela é representada através dos seguintes signos:

\section{Guarda-chuva}

'Anteparo contra o mal', não permite que a pessoa, ou casal, venha a 'se molhar' ou seja contaminado pela chuva que cai (figura da Aids). Esta imagem é particularmente representativa, porque sugere várias associações: a chuva cai ao acaso, não há 'alguém' ou algo a que se possa culpar porque chove; a chuva é impessoal, cai sobre todos igualmente; a decisão de portar o guarda-chuva é individual e seu uso requer ação específica e voluntária.

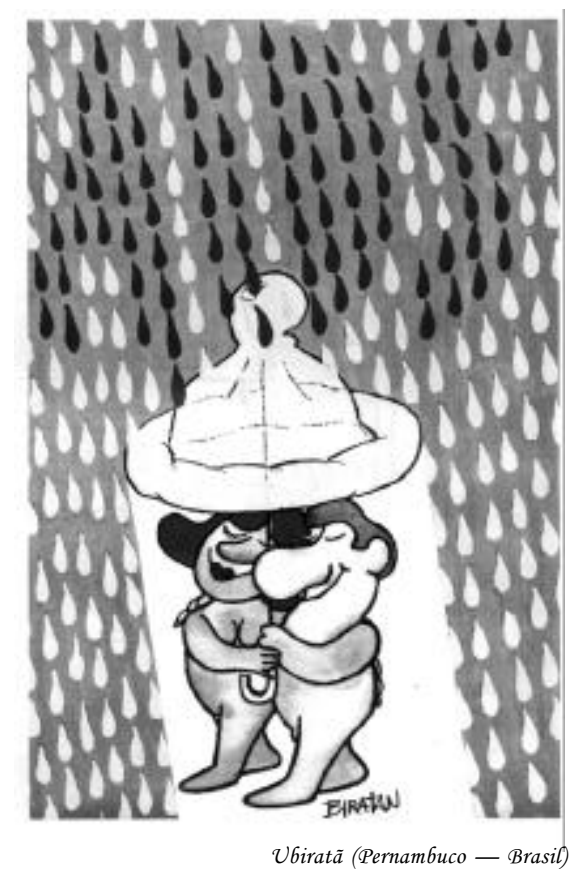

\section{Bóia salva-vidas, rede de bombeiros}

Representada como uma bóia salva-vidas, a camisinha adquire um valor que originariamente não tem, que é a possibilidade de salvar alguém que já esteja em posição de extremo perigo, a ponto de afogar-se. Representada como uma rede de bombeiros, de igual modo: há uma pessoa (ou um casal) em perigo, em um prédio em chamas, que se lança em uma grande rede sustentada por vários bombeiros. Se considerarmos que tais pessoas estão em perigo porque já se encontram infectadas, a camisinha ofereceria proteção para outros, não mais para elas. E se considerarmos que o perigo que rodeia tais pessoas é o perigo de contaminação, incorremos na visualização de um quadro dramático e exagerado, onde a sociedade como um todo é comparada a um mar agitado pronto a tragar vidas ou a um prédio em chamas. Embora esta última idéia seja um dado a considerar, acredito que o uso de tais imagens para representar a camisinha tenha mais relação com o signo em si (a bóia) e sua força como referencial de salvação do que com as situações prefiguradas. 


\section{Redoma}

Representada como uma redoma protetora a envolver de modo inteiro e completo uma pessoa ou um casal, a camisinha é posta como divisória entre um mundo interno e imaculadamente protegido e um mundo externo exposto às intempéries (entre elas, a Aids). Mas alguns cartuns invertem essa situação. Nesse caso, o mundo externo está protegido, já que é a Aids (não o casal) que está envolvida pela redoma. A redoma continua sendo divisória entre dois mundos, mas o ponto de vista mudou completamente. De qualquer forma, a representação da redoma leva à idéia de separação, de distinção entre um-que-estáfora e um-que-está-dentro.

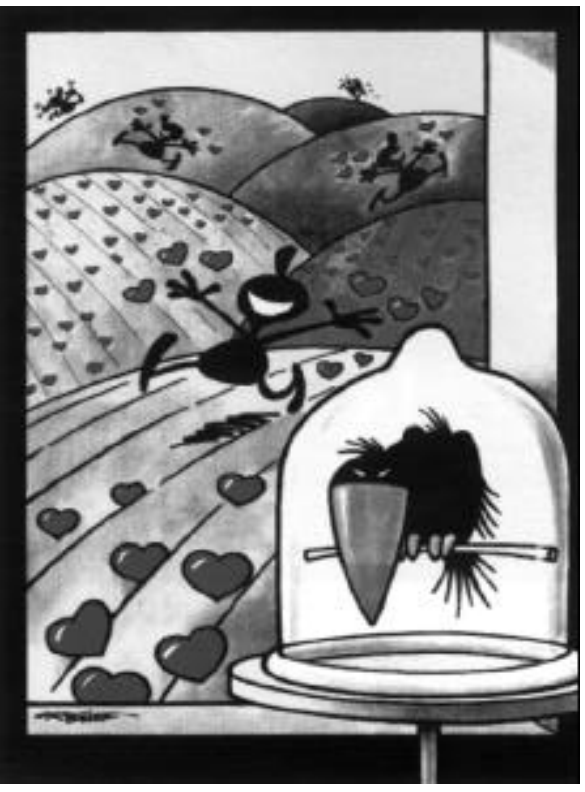

Origoni (Itália)

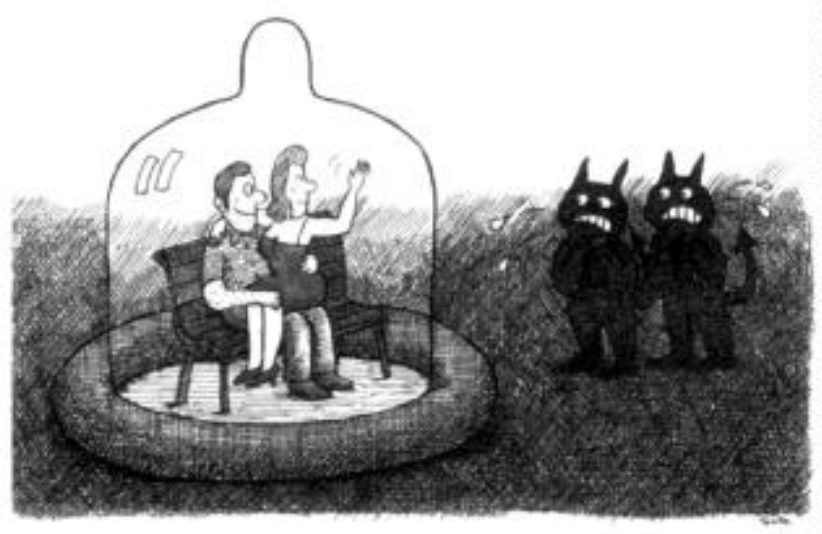

Ento (Japão)

\section{Pára-quedas}

A representação da camisinha como um pára-quedas traz a idéia de sustentação, de diminuição de risco. Por conseguinte, traz implícita a idéia de risco, de um salto no vazio. Em vários cartuns, o pára-quedista aparece manobrando com absoluta segurança o pára-quedas/ camisinha, invariavelmente pousando num vale cujo formato representa o corpo da mulher ou num monte pontudo. No primeiro caso, há alusão a uma relação heterossexual, enquanto no segundo, à homossexual. Nos dois casos, há a conotação de que existe um salto, um risco iminente em se lançar a uma relação sexual, mas este risco é controlável e torna-se quase eliminado em função da segurança do pára-quedas. Além disso, está implícita a noção de que ou se assumi o risco do salto ou não. Mas saltar sem pára-quedas, todos sabem, é morte certa.

\section{Rede de caçar borboletas}

Esta é uma imagem que comporta como nenhuma outra neste grupo a idéia do lúdico: a camisinha é uma rede de caçar borboletas, e os cartuns onde aparece retratam basicamente 
três situações: um homem 'caça' mulheres voadoras com asas de borboletas; uma mulher 'caça' pequenos pênis voadores; e alguém 'caça' o vírus da Aids. Pode-se notar que as duas primeiras representações são semelhantes entre si e completamente diferentes da terceira. Enquanto a caça a mulheres e pênis com a rede/camisinha diz respeito à proteção no relacionamento sexual, incluindo a alegria de assim poder 'caçar em segurança', a terceira imagem inverte o foco e significa que a Aids é que deve ser 'caçada' e 'aprisionada', ela é que 'voa como uma borboleta'. Novamente, o uso da mesma imagem sob pontos de vista diferentes.

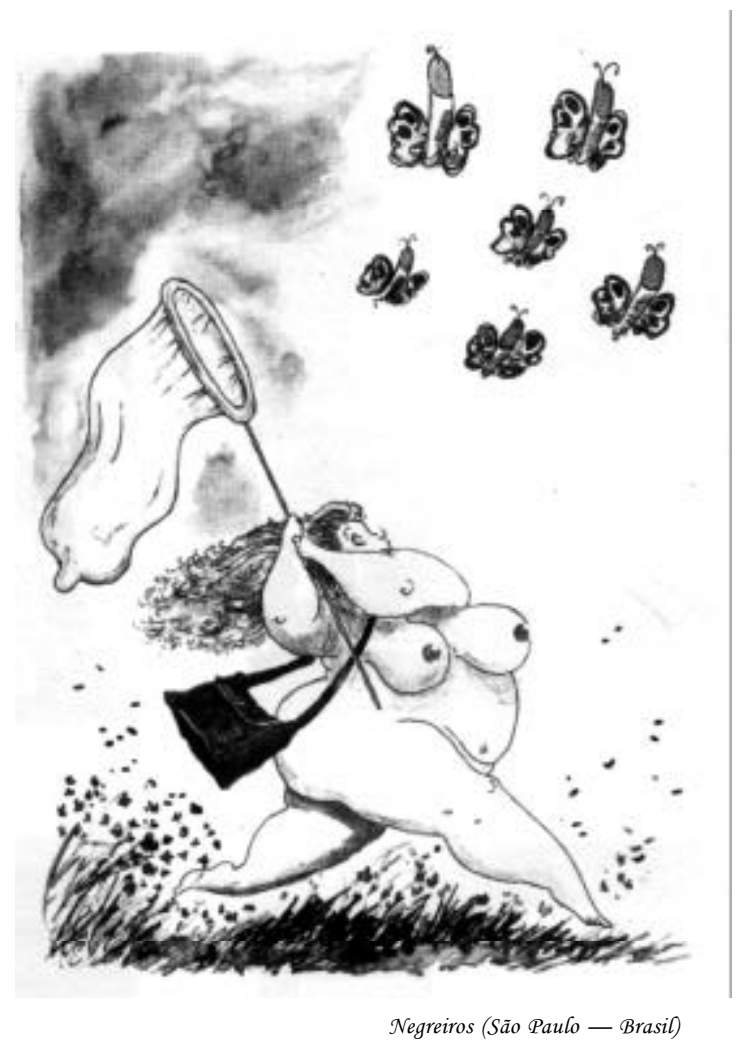

O uso da imagem e da representação da camisinha ultrapassa sua denotação puramente sexual e avança como signo de proteção em si. Por vezes, ela é representada protegendo não apenas indivíduos da contaminação do vírus através do ato sexual, mas protegendo o casamento da infelicidade, o planeta da desgraça e, sobretudo, protegendo o amor. O conhecido signo do 'coraçãozinho' para representar o amor é percebido muitas vezes sendo envolvido por uma camisinha. Esta idéia (camisinha protegendo o amor) mostra que o artista, e conseqüentemente a sociedade, não desfez (ou não quis desfazer) a ligação sexo/amor, e que esses dois conceitos estão interligados e promiscuídos. Grande porcentagem dos cartuns que tratam do tema apresentam visível dificuldade em separar amor e sexo para fins de prevenção. Numa visão simplista, protegendo-se o sexo está-se automaticamente protegendo o amor e seus valores mais sagrados. Por outro lado, na proteção ao amor está embutida a proteção ao sexo. A questão então é: vincular uma idéia pode ser um empecilho à idéia de prevenção científica e objetiva? Não estarão embutidas, aqui, noções e juízos de valor acerca de uma questão moral sobre o sexo e preferências sexuais, envolvendo sexo 'com' e 'sem' amor? 
Com relação especificamente ao amor, a camisinha aparece protegendo:

a) $\mathrm{O}$ amor. $\mathrm{O}$ amor é frágil e precisa ser protegido de uma ameaça externa (a Aids).

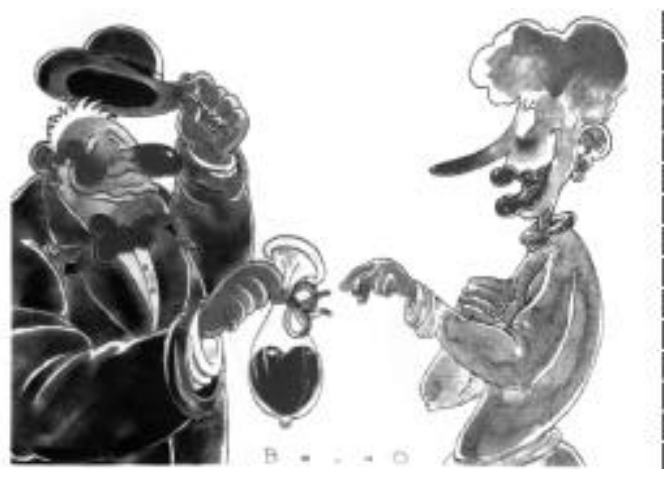

Bruno Croácia)

b) Do amor. $\mathrm{O}$ amor não é confiável e as pessoas precisam ser protegidas do amor (identificação, implicação: amor $=$ sexo $\rightarrow$ sexo $=$ aids).

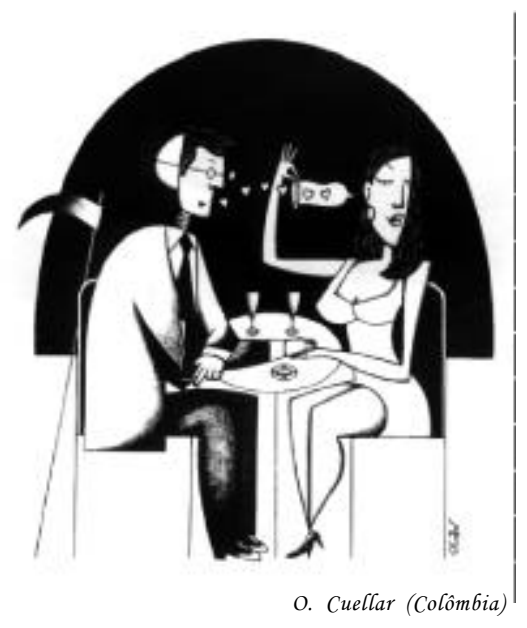

c) Para o amor. $\mathrm{O}$ amor em si é confiável mas não pode ser plenamente realizado sem a contribuição da camisinha, porque existe um mal externo a ele. Amor $(=$ sexo $)+$ camisinha $=$ Amor pleno (seguro).

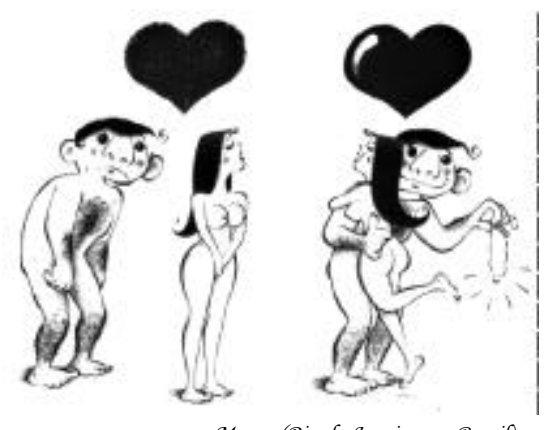

Marco (Rio de Janeiro - Brasil) 
Esta última representação aborda a questão levando em conta escolhas pessoais e não escamoteia a complexidade das situações que envolvem conceitos como amor e sexualidade.

A camisinha, nos cartuns, torna-se um signo tão forte de proteção que sua imagem é utilizada envolvendo todo o planeta (o globo), representando não apenas segurança para a população mundial, mas ganhando o sentido de proteção ambiental e ecológica. Em vários cartuns ela aparece também encapando a ponta de seringas, representando a prevenção contra a Aids transmitida por meio do uso de drogas injetáveis. É nesta imagem, onde toda vinculação com a realidade objetiva da prevenção desta via de contaminação é completamente rompida, que a representação da camisinha como símbolo absoluto de proteção pode ser claramente dimensionada.

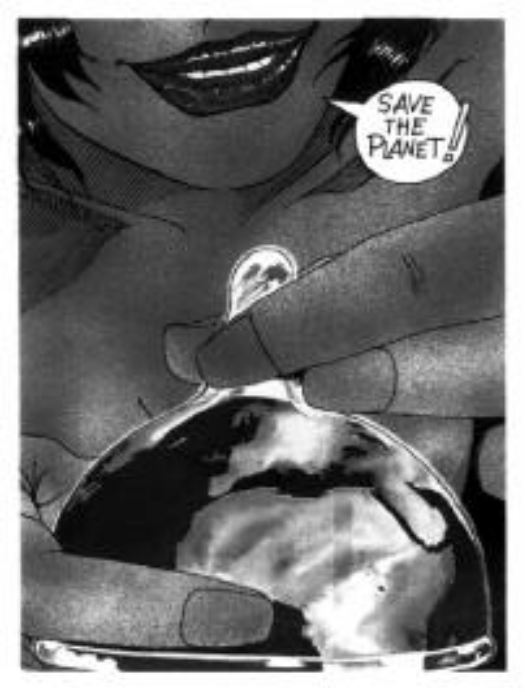

Líbero/Paulo Garfunkelel (São Paulo - Brasil)

À parte isso, a idéia de 'proteção' em si está presente em muitos trabalhos, mesmo sem alusão específica ao preservativo. É significativa a quantidade de cartuns que se apóia na idéia do amor e da fidelidade como proteção contra a Aids. Nestes cartuns, onde não há a presença nem a alusão à camisinha, tais valores, de modo implícito ou explícito, são tidos como suficientes para proteger os indivíduos e a sociedade contra a Aids que, por extensão e no pólo oposto, passa a ser vista como doença da imoralidade, da promiscuidade, da infidelidade e da 'anormalidade'.

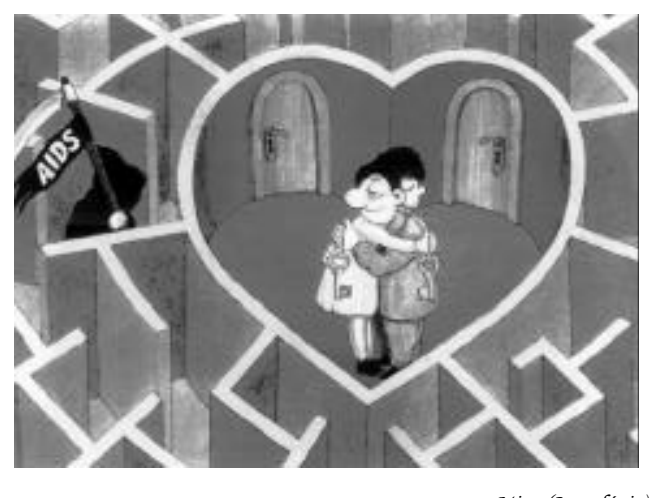

Miro (Iugoslávia) 


\section{A Aids}

A Aids é diretamente personificada em 14,9\% dos cartuns analisados, principalmente de cinco maneiras:

a) Como um monstro, representando terror e perseguição. Esta imagem remete a horrores antigos, mitológicos, que ultrapassam em muito o caráter de doença, carregando em si o pânico do não-conhecido.

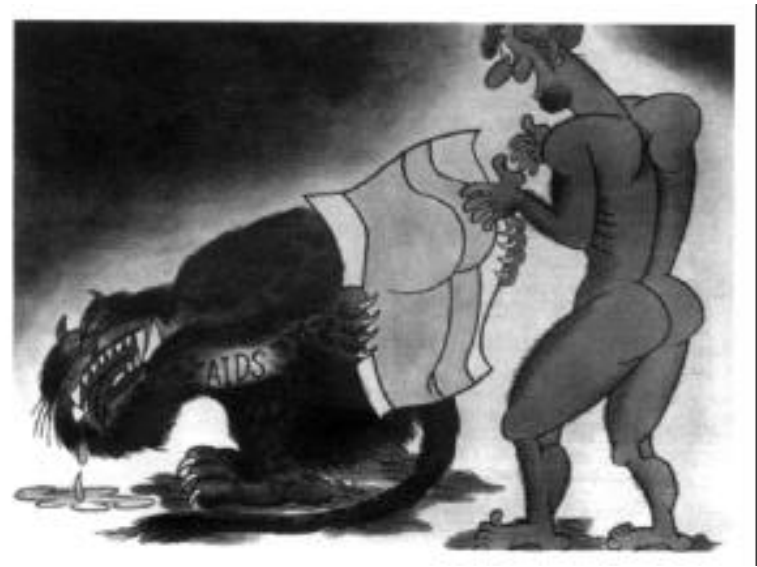

Xia Dachuan (China)

b) Como vírus, revelando impessoalidade e sua natureza biológica. Mas, na grande maioria das vezes em que a Aids é assim retratada, tais vírus parecem pequenos monstrinhos devoradores.

c) Como a morte, seja como um esqueleto ou como a clássica figura negra com a foice. Aqui a doença passa a ser representada não por seu agente ou por suas implicações, mas por sua (suposta) conseqüência última. Esta é a forma predominante de representação nos cartuns analisados, revelando a existência de forte vínculo no imaginário entre Aids e morte.

d) Como o diabo. A escolha deste signo envolve a dicotomia bem $/ \mathrm{mal}$. A Aids aqui é vista não apenas como algo que é mau em relação à saúde do homem, mas como o mal em si.

e) Como a palavra Aids, onde as letras podem ou não estar ligadas entre si formando uma espécie de 'ser'. Maneira abstrata e convencional de representação, calcada exclusivamente na força do imaginário à simples menção do nome da doença. Neste caso, "o nome é a coisa".

Representações da Aids como a morte e o diabo estão profundamente enraizadas no imaginário medieval, quando pestes, pragas e doenças eram também assim representadas. Ambos os signos remetem à inevitabilidade, ao acaso, ao trágico e ao mal absoluto. Ambos trazem em si o germe da maldição, do castigo. "A morte é o salário do pecado", e esta 'morte' ceifadora e negra está atavicamente relacionada à causalidade. De modo semelhante, a figura do diabo está em oposição à figura de Deus: quem está nas garras de um, certamente não tem o outro.

Outras representações da Aids, mesmo que ocasionais nos cartuns estudados, merecem atenção mais detalhada: algumas vezes ela é personificada no sangue, no espermatozóide, no 
sexo e mesmo no amor, no homossexual e na mulher. Estas vinculações nem sempre são tão diretas como as representações listadas anteriormente, mas contêm pontos de partida para novas considerações. Assim, a Aids é também personificada:

a) No sangue. Sinal de vida, o sangue passa a ser sinal de morte. A Aids é o sangue da transfusão (que, de generosa doação de vida torna-se agente da morte), o sangue do 'drogadito' (contaminado pelo 'pecado'ou pela 'fraqueza') e o sangue da própria mãe gestante (que ao mesmo tempo alimenta a vida e a condena). A razão da personificação da Aids no sangue é óbvia: o veículo é tomado pelo agente.

b) No espermatozóide. De modo semelhante ao processo semiótico anterior, o veículo é confundido com o agente, com uma importante diferença. $\mathrm{O}$ homem passa a estar também relacionado ao agente transmissor, passa a ser mesmo a causa, o que porta o mal.

c) No sexo. A questão moral emerge com toda força nesta representação onde o que deve ser evitado passa a ser o sexo em si, o ato sexual. Esta imagem varre para baixo do tapete toda e qualquer discussão a respeito de escolhas e possibilidades de prevenção, sugerindo que é a sexualidade (mais ainda do que o ato sexual) a causa e o agente da Aids.

d) No amor. Esta representação coloca em evidência o fato já referido anteriormente: há uma confusa simbiose de conceitos, e o amor é tomado pelo sexo.

e) No homossexual. Há poucos cartuns que enfocam o tema da homossexualidade, mas em $50 \%$ dos casos, quando o fazem, o conteúdo conota discriminação e preconceito. Nas situações em que a Aids é confundida com o homossexual, é suscitada a idéia de que a doença está restrita a tal grupo social, que ela é própria de tal grupo e, pior, que tal grupo é a causa mesma da doença. A maioria dos cartuns que revelam os preconceitos mais explícitos são do Irã.

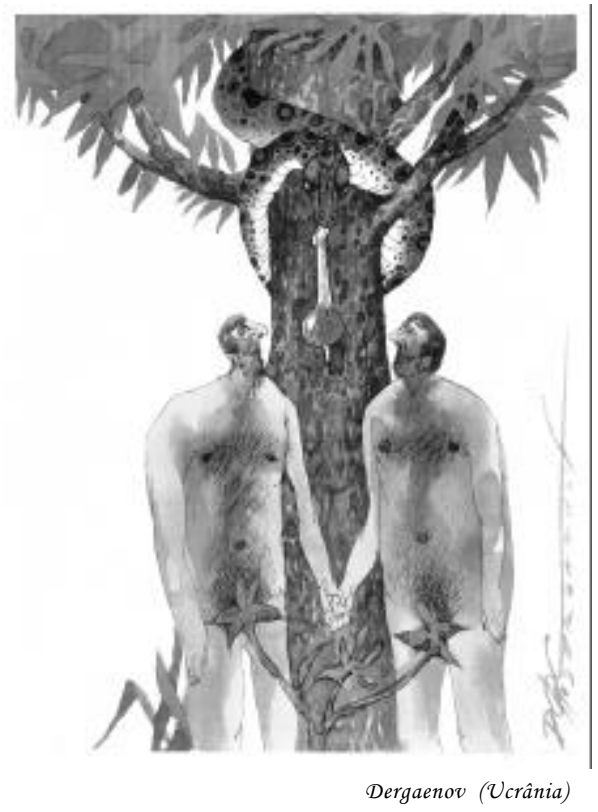




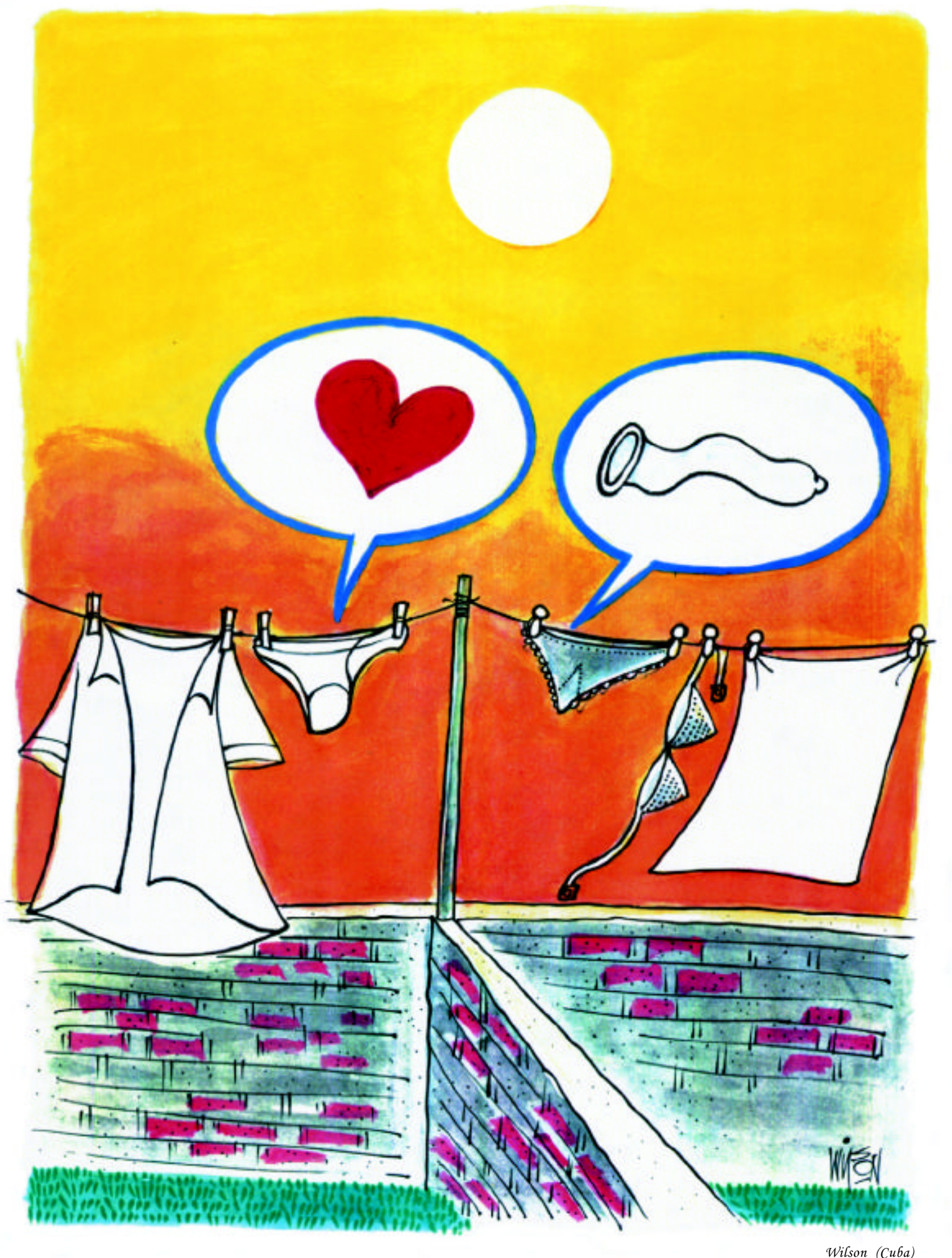




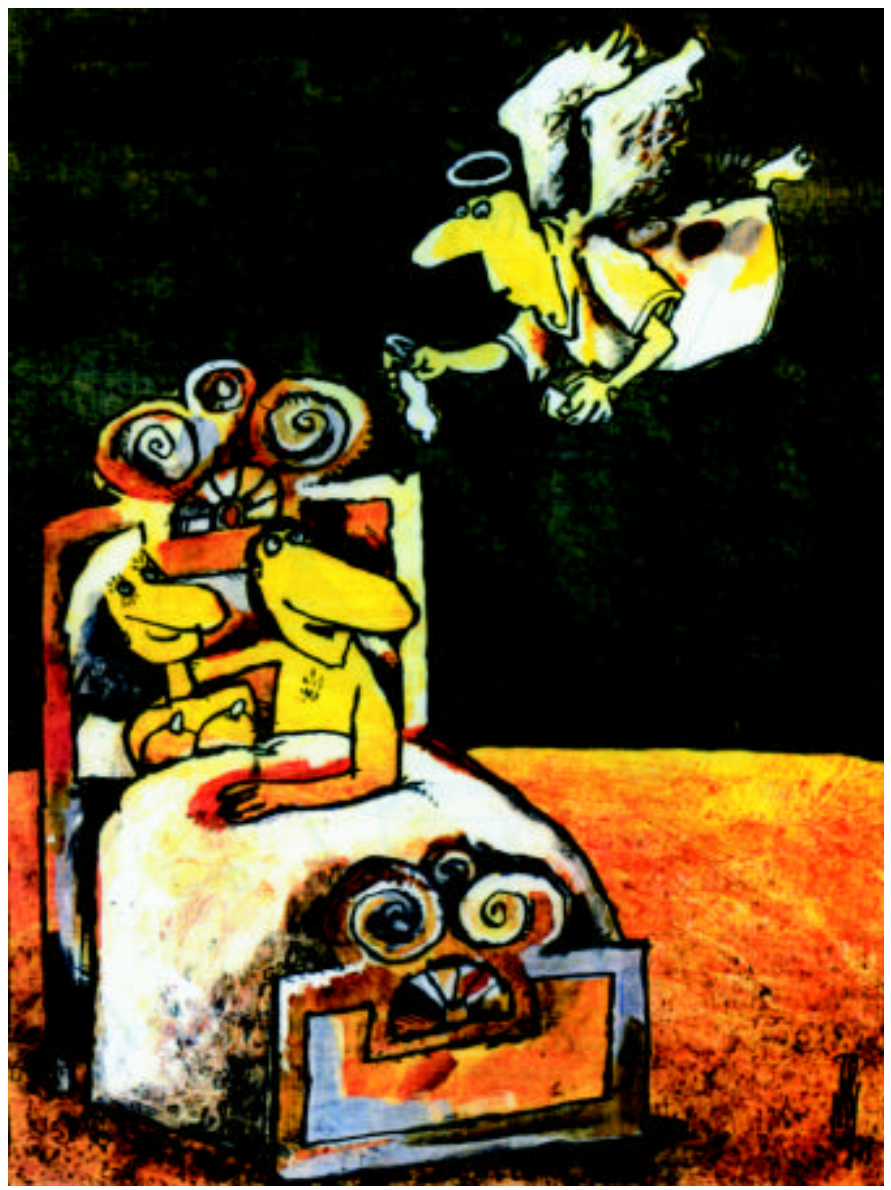

Tomy (Cuba)

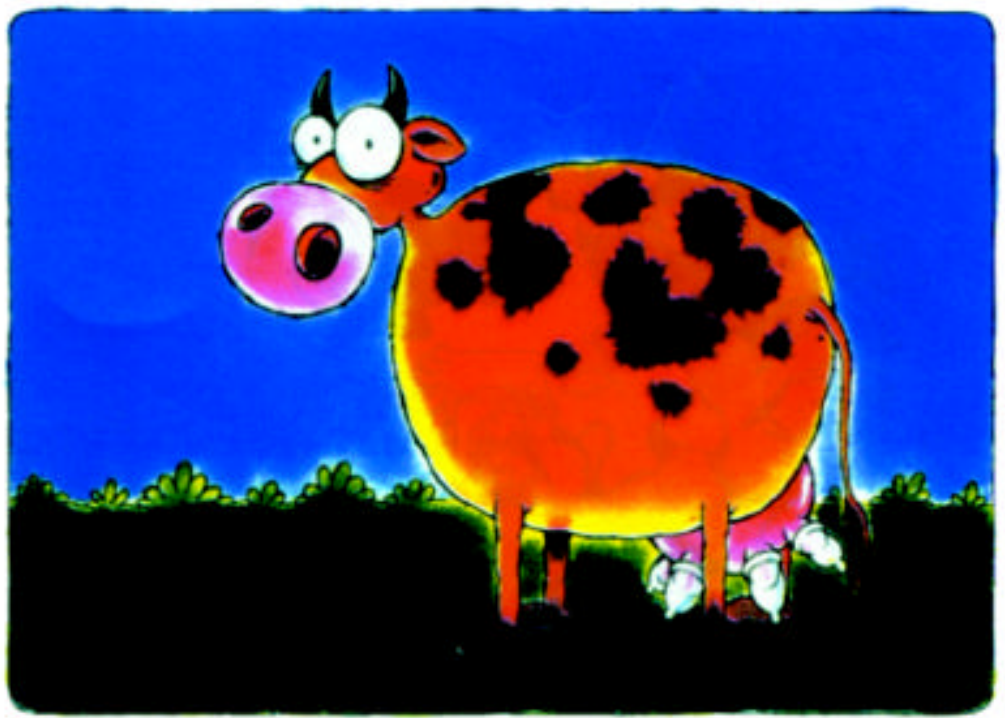

Hamid Reza Azarkẹheil (Irã) 


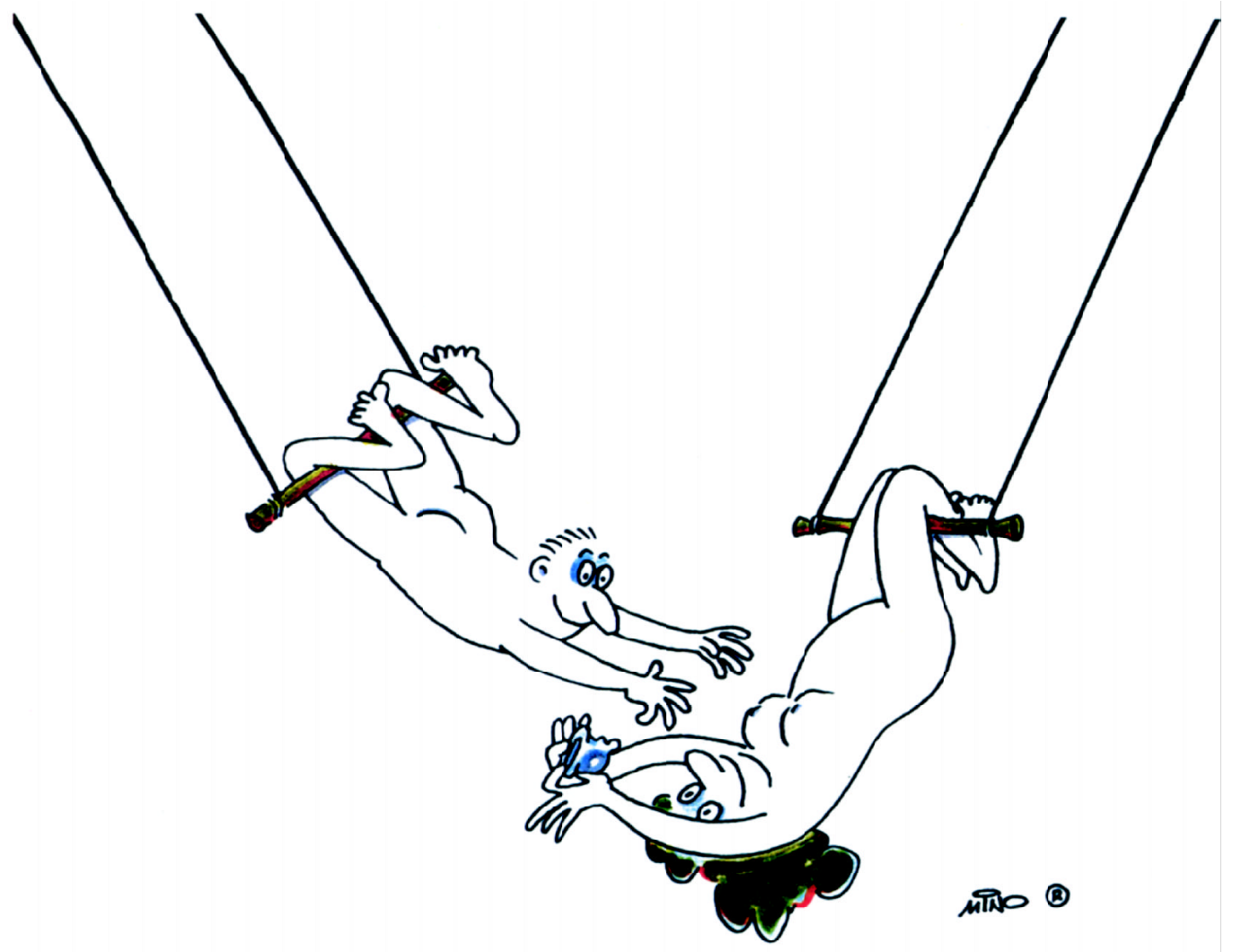

Mino (Brasil)

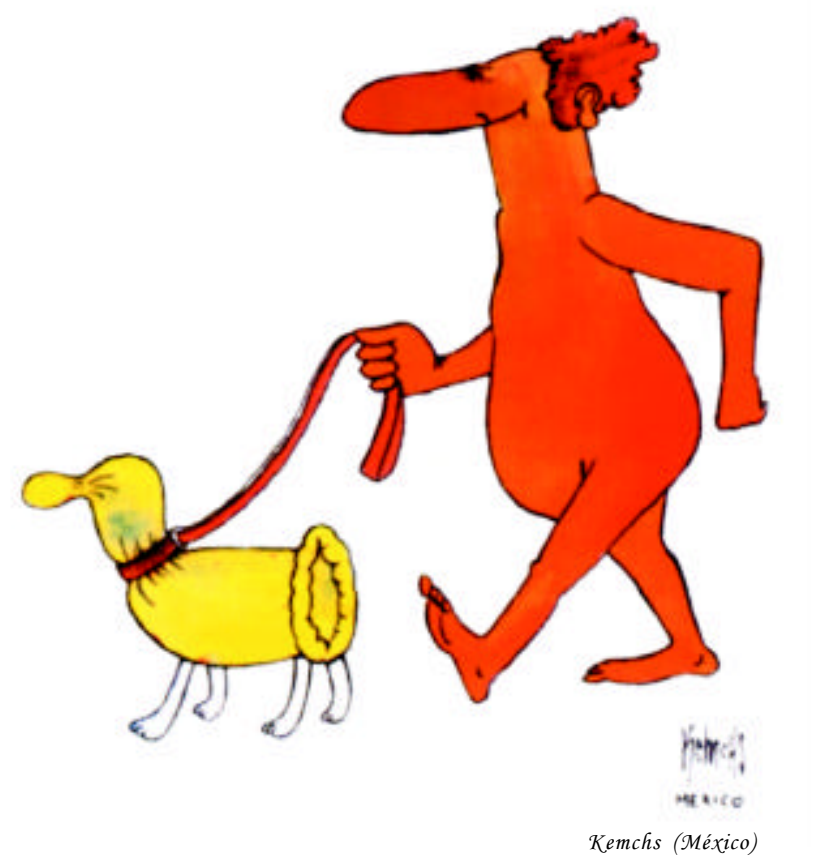

MAR.JUN. 2001213 


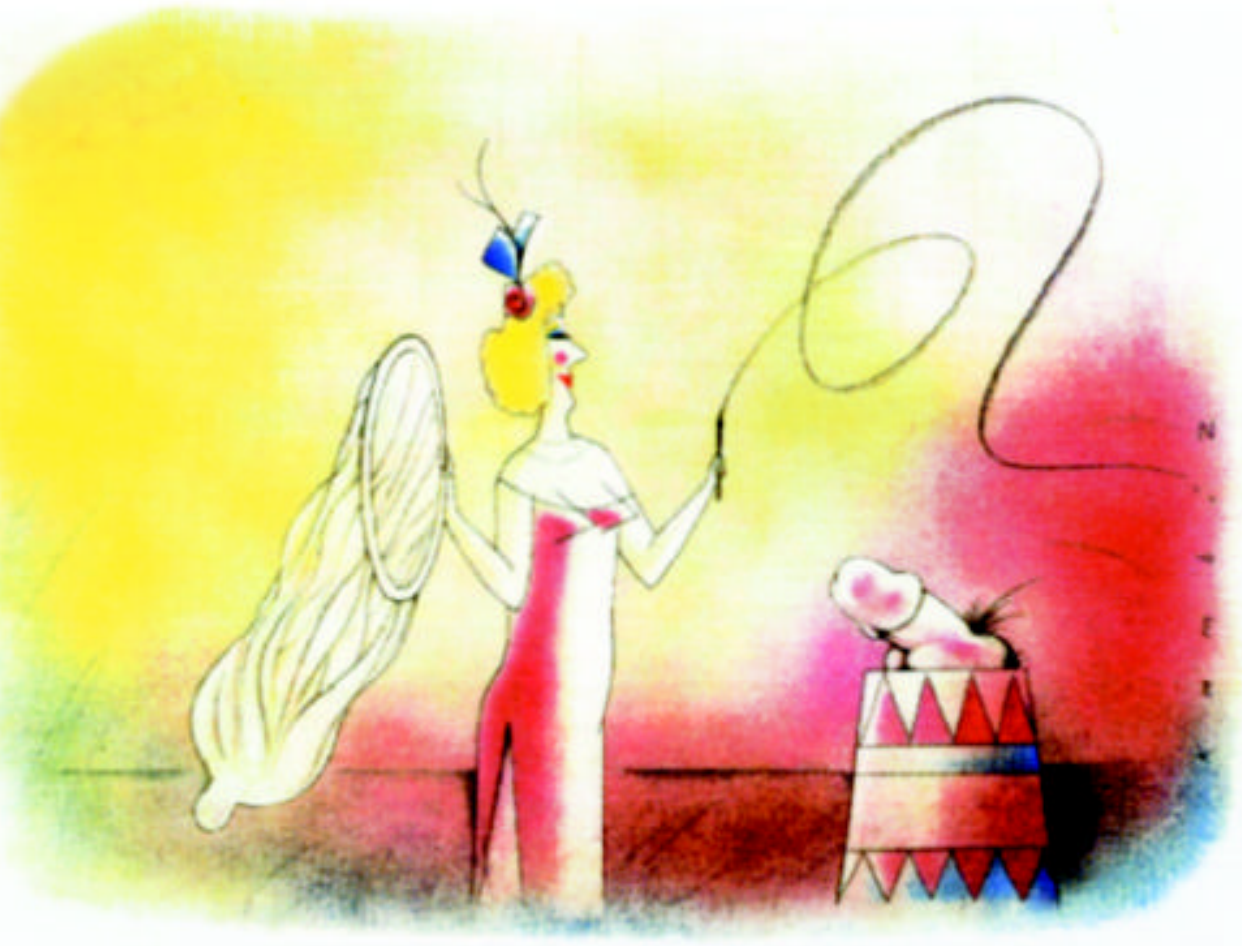

Kambiz (Irã)

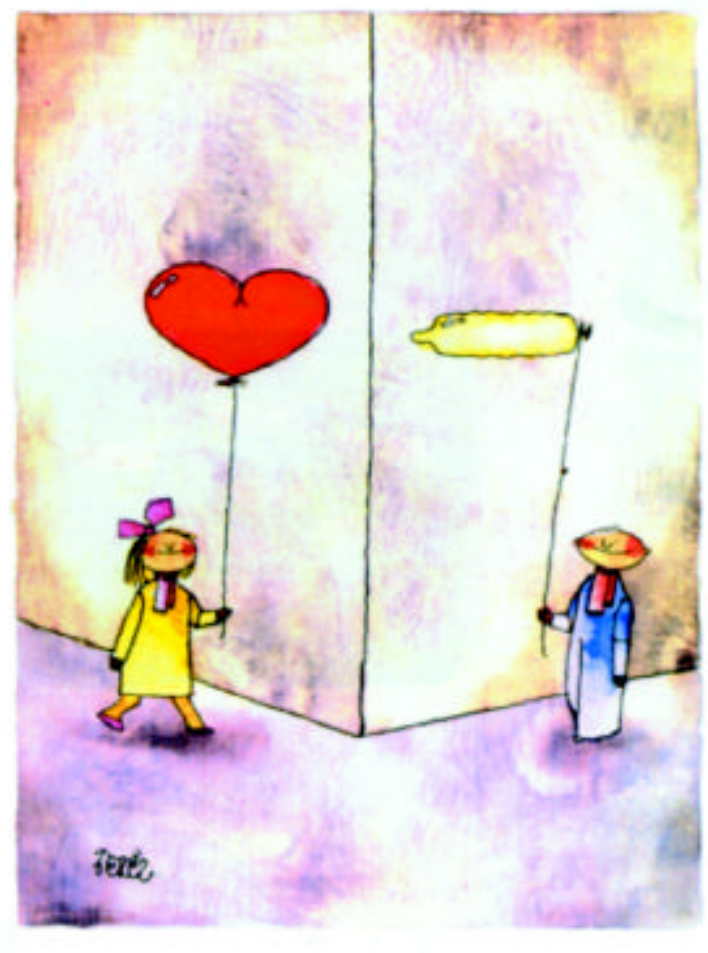

Jeréz (Cu6a) 
f) Na mulher. Da mesma maneira, a Aids é personificada na figura da mulher. Em alguns cartuns, esta personificação se dá na mulher-prostituta. A incidência dessa imagem noscartuns cubanos é bem grande, e a razão é facilmente compreensível, em virtude da cultura do país e do esforço dos organismos de governo em rejeitar e erradicar a prática da prostituição. Mas é também comum a vinculação da Aids à mulher em si. Um dos cartuns mais sugestivos mostra uma mulher nua e, na região pubiana, a palavra Aids e o símbolo da caveira. Assim, não só a sexualidade é posta em questão e sob suspeita, mas também a mulher, a Eva que leva o mundo ao pecado e, conseqüentemente, à morte.
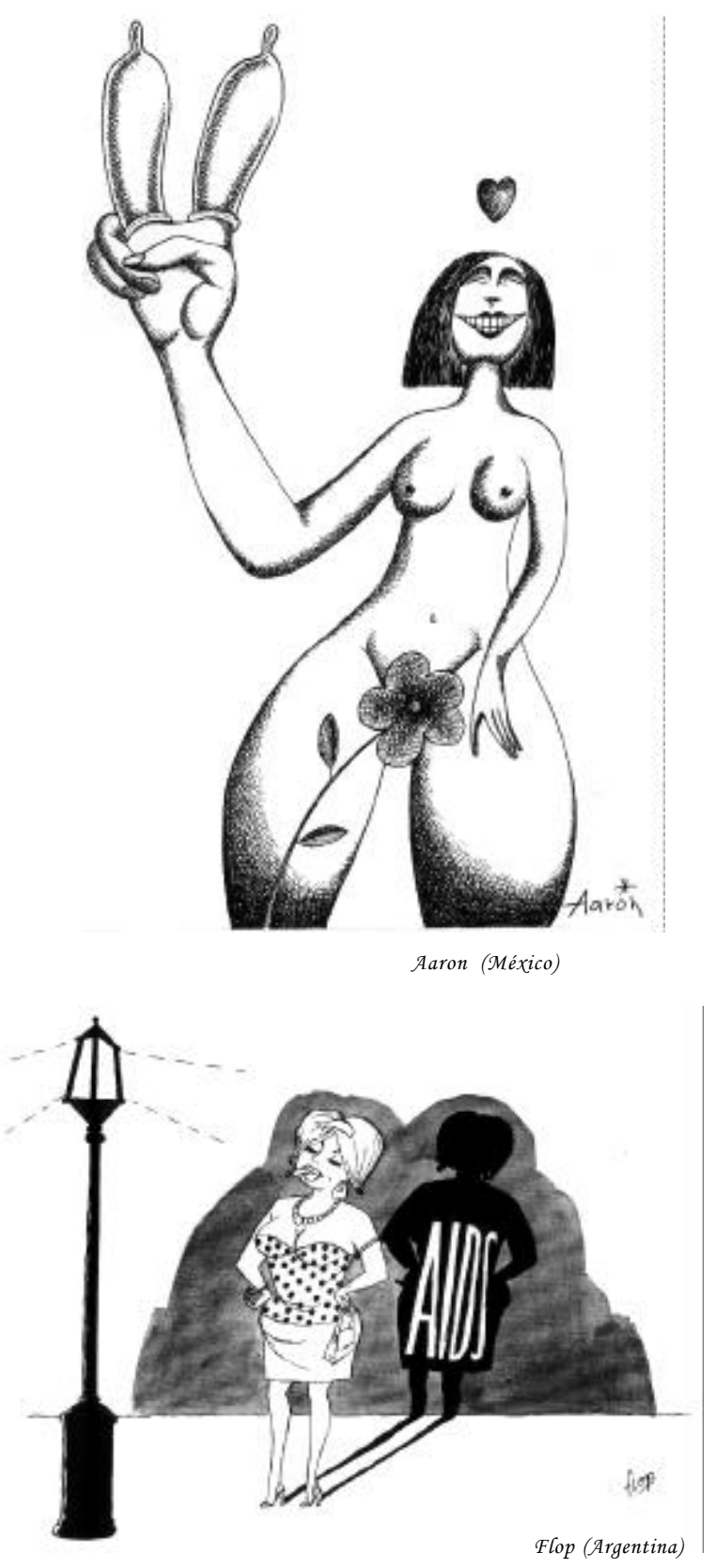


\section{O Cupido}

Há inúmeros 'cartuns repetidos', num universo de análise tão grande. Uma mesma idéia é encontrada em cartuns brasileiros, europeus e chineses. A imagem que pode ser considerada representativa desta bienal e deste tema é: um casal sentado em um banco, enamorado, enquanto o Cupido aponta a flecha (encapada com uma camisinha) em sua direção. A combinação destes elementos, com maior ou menor variação, foi notada muitas vezes, em todos os três grupos de cartuns. As principais variações são: a flecha está apontada para um 'coraçãozinho' do amor; não há a cena toda, mas apenas a flecha encapada, já fincada no coração; a flecha não está encapada, mas carrega, amarrada, uma camisinha fechada. A mais original idéia desta 'série' mostra um casal prestes a ter uma relação e o homem olhando desconfiado para a camisinha que iria usar: ela está furada, atravessada pela flecha do Cupido, que envergonhado, ao fundo, tenta sair de fininho.

Esta imagem torna-se um poderoso signo de prevenção por inserir a idéia de antecipação. Antes mesmo de o Cupido lançar sua flecha, antes mesmo de a paixão (ou desejo) ser definitivamente deflagrada, já há um pensamento anterior a respeito do uso do preservativo. A possibilidade do amor (nesta imagem sofrendo a mixagem com a idéia de sexo) já contém a necessidade da prevenção. $\mathrm{O}$ dado negativo desse cartum é que tal pensamento acerca da prevenção não está vinculado aos enamorados, mas a uma instância superior e abstrata (o Cupido, o amor, o desejo).

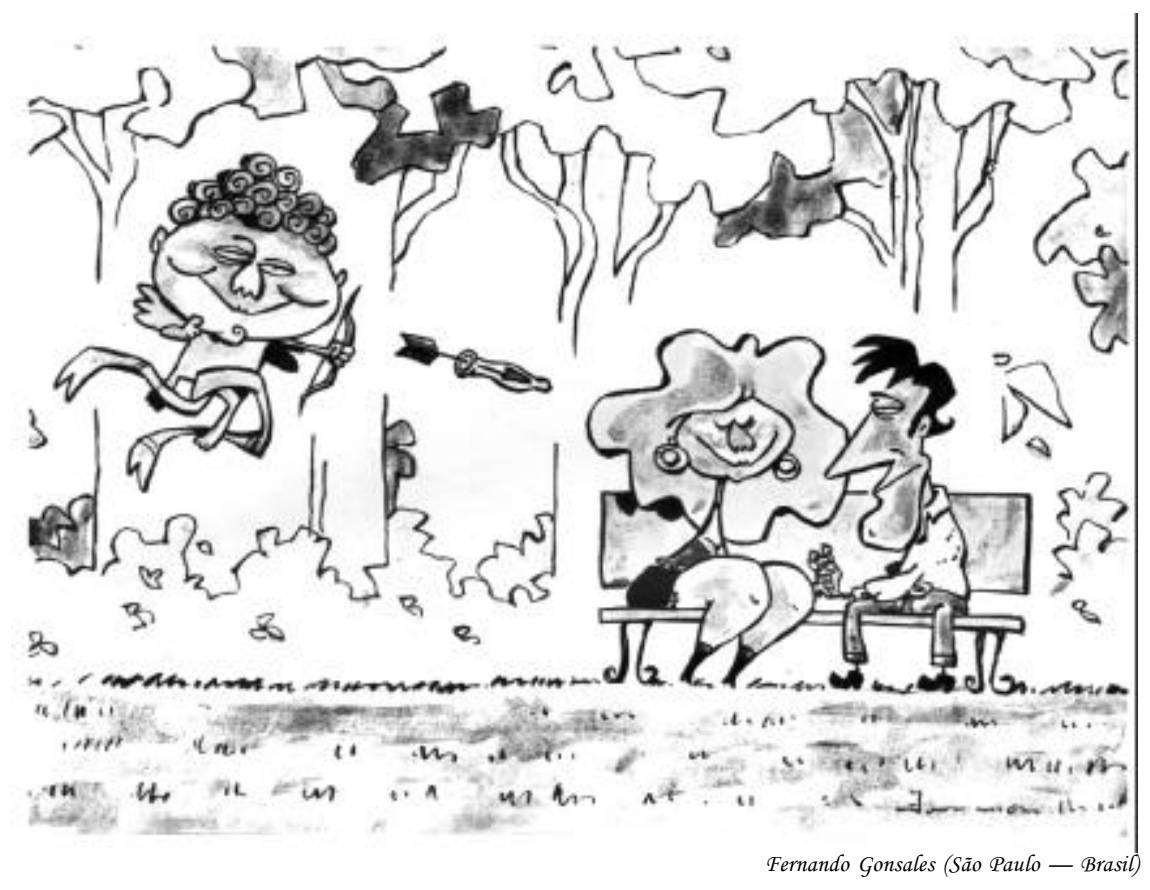

\section{Adão e Eva}

A referência a este mito costuma ser comum em certames de humor, muito mais quando o tema do concurso propicia uma abordagem de assuntos referentes à sexualidade. Adão, Eva, a maçã, a serpente, a árvore e, é claro, a camisinha é outro conjunto de elementos muito citado e exaustivamente combinado. As variações mais comuns são: a serpente entrega a 
maçã e um dos dois (predominância da mulher) apresenta uma camisinha; os dois têm a maçã nas mãos, enquanto a serpente provê a camisinha. A idéia mais original mostra Adão e Eva ao pé da árvore, com a maçã, enquanto a serpente enrolada na árvore é a própria camisinha.

Há uma interessante inversão do mito original, na maioria dos cartuns que enfocaram o tema: não é mais a serpente o problema e a causa do mal, mas a maçã. A serpente passa a ser, assim, surpreendentemente um veículo da segurança e um signo da prevenção, ao oferecer ao jovem casal encantado pelas delícias da sexualidade a proteção da camisinha. Esta aparentemente incompreensível mudança no mito tem raízes na concepção já citada anteriormente, onde a sexualidade é o maior perigo a ser evitado. Nesse caso, não há um 'artífice' da sexualidade e a idéia de uma 'serpente-diabo' a oferecer tentações está relegada a um segundo plano. Não há nada exterior à sexualidade, e sim, talvez por causa da vinculação ao tema Aids, é a maçã, a sexualidade em si mesma, que contém o mal e que é o próprio mal a ser evitado.

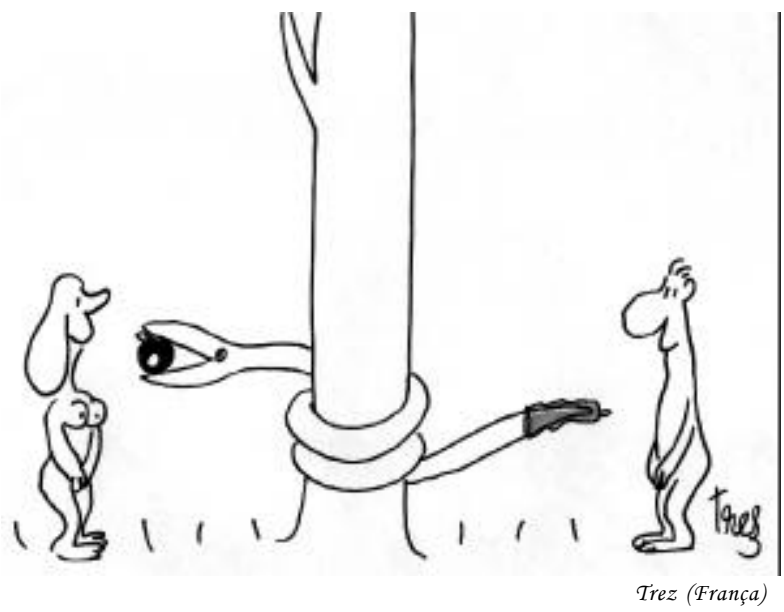

\section{O riso, a Aids, a saúde}

"Aids é coisa séria", dizem, "e com coisa séria não se brinca." Saúde também é coisa séria. Sabemos o que é o riso (iluminador e iluminado, criador e criativo, trágico), mas o que será o 'sério' ou a 'coisa séria?? Esta 'coisa séria' (com a qual não se brinca) pode ser definida, por oposição, como 'aquilo que não comporta o riso'. De coisas importantes não se deve rir, ou só rimos daquilo que não é importante. Se é importante, e se rimos, somos levianos ou não compreendemos a importância dessa coisa.

Demócrito (apud Alberti, 1999) era chamado o 'filósofo que ri' porque, obviamente, ria. Poucos fragmentos atribuídos aos filósofos pré-socráticos chegaram até nós, mas conta-se que Hipócrates, chamado pelos habitantes da cidade de Abdera para examinar Demócrito, recebeu a notícia de que este estaria gravemente enfermo, à beira da loucura, pois se ria de qualquer coisa. Uma só visita, porém, foi suficiente para que o médico atestasse e reconhecesse que o filósofo, ao contrário, estava mais são e sábio do que nunca, justamente porque se ria. E de que ria Demócrito? "Rio do homem cheio de loucura e vazio de toda ação direita, que se comporta puerilmente, que vai até o fim do mundo procurando ouro e prata, trabalhando sempre para adquirir mais bens..." Demócrito ri de 'coisas importantes' como a busca do ouro e da prata, ri do 'trabalho que visa os bens'! Mais adiante, o filósofo diz: "Quando você 
entender o meu riso, sei que o estimará, tanto para você quanto para seu país, como melhor remédio e cura que há em sua legação, e disso poderá fazer sábios os outros." Demócrito relaciona o riso não à loucura, mas à sabedoria. O mesmo diz Roberto Gomes (1977), ao vincular o riso à essência de uma alma brasileira e efetuar uma providencial distinção entre o 'sério' e o 'a sério': "Se levo a sério, isto é algo que sai de mim em direção ao objeto da seriedade; se sou sério, me coisifico como objeto de seriedade."

O riso é iluminado e iluminador por transgredir o senso-comum e o bom-senso, por iluminar uma nova ótica e inaugurar uma nova lógica. $\mathrm{O}$ riso de Demócrito era iluminador porque via como 'pueril loucura' o que era tido por importante. Não só é possível, como é preciso rir das coisas importantes. Neste 'riso' estão implícitas, por exemplo, as verdadeiras 'importâncias' das ações públicas, das promessas de governo, das políticas e das idiossincrasias do sistema de saúde. O riso é também criador, e o início desta 'criação' é a destruição, a identificação do que é mecânico, do que é falso, do que não é vivo. A partir daí, o riso instaura uma verdadeira liberdade: de escolha, de atitude, de pensamento e de ação. É preciso rir da Aids, descobrir-lhe as fraquezas, desnudar-lhe a face, desmistificar seu pathos. É preciso rir das 'coisas sérias' para poder lidar com elas sem temê-las, com verdade e ousadia.

E, por fim, o riso é trágico. "Qual é a diferença entre o vento e Ayrton Senna? O vento faz a curva!" Esta e mais uma série interminável de piadas sobre a morte do mais querido piloto brasileiro fez muitos torcerem o nariz e reclamarem da falta de respeito. Ayrton Senna não morreu de velho, nem em condições, digamos, minimamente esperadas. Considerado o melhor piloto do mundo, no auge da forma física e técnica, estava fazendo o que gostava e dominava como ninguém. E encontrou a morte exatamente nesse momento. A tragédia não é a morte, mas a gratuidade da vida. Vislumbra-se, nesses momentos, que não há ninguém no controle, que não há controle algum, que não há ordem na natureza nem porquê na existência. Há apenas o acaso, o caos. E diante deste fato que, em tais momentos, agigantase sobre a cabeça dos seres humanos, só temos três alternativas: ou sucumbimos, ou nos conformamos, ou nos erguemos. Sucumbir significa não entender o que acontece e por isso mesmo não aprovar. Conformar-se significa não entender o que acontece e mesmo assim aprovar. Erguer-se significa tentar entender o que acontece e aprovar. Uma dessas formas de 'aprovação' é o riso. Este é um riso exterminador, que celebra a vitória do caos sobre a aparência de ordem, reconhecendo o acaso como verdade (Rosset, 1989, p. 197), a existência como gratuita. Este reconhecimento torna possível a lida saudável com a coisa trágica.

Saltando de uma abordagem 'descritiva', onde tentamos analisar o que acontece entre o cartum e a sociedade, entre a idéia e o objeto, e onde estabelecemos pontos importantes a respeito do riso e suas funções, para uma abordagem mais objetiva, onde procuraremos responder a questões acerca do humor e sua relação direta com o trabalho de educação e prevenção, vamos encontrar algum embaraço. Dentre as frases publicadas no Regulamento e no Catálogo da Bienal, proferidas por pessoas célebres, artistas, jornalistas e cientistas, dois 'discursos' são comuns:

a) O humor é uma maneira "suave e alegre" de abordar um tema "duro e triste".

b) O humor é uma "ferramenta para modificar comportamentos".

Há, ainda, a comuníssima confusão entre 'humor' e 'bom humor', já abordada no início desse artigo. 
Chegamos à constatação de que o fato de sabermos algo a respeito do riso e do riso trágico, algo acerca dos 'mecanismos' do riso e de suas funções não nos é suficiente para que possamos responder objetivamente acerca do que pode ser feito, em relação à educação em saúde, utilizando o humor como ferramenta. A questão é ainda anterior: será que essa relação de 'utilização' do humor é possível? Uma análise dos discursos mencionados, mesmo superficial, revela algumas incoerências e inconsistências. As inconsistências ficam por conta do senso comum. Percebemos que não há implicação lógica neste 'tratar coisas tristes com humor' com uma 'mudança de comportamento'. Notamos que, na maioria das vezes, usam-se esses conceitos para justificar qualquer coisa e, ao mesmo tempo, nada.

Embora seja necessário 'rir da coisa séria', rir do importante para confirmar ou negar essa importância, em que medida podemos pensar numa utilização racional e planejada do humor, em oposição à forma intuitiva e espontânea pela qual o riso acontece nos meios de comunicação e na sociedade? Qual seria, nesse caso específico, o benefício real em abordar o sério com humor? Essa 'prática' não poderia nos levar, por outro lado, a um efeito contrário, o de banalizar o que deveria ser singular e o de reforçar ainda mais certos preconceitos sociais? Notemos que não há contradição entre o 'riso de Demócrito' e o que dizemos agora: enquanto o primeiro está naturalmente enraizado na sociedade e no ser humano como forma dinâmica e espontânea de criação, iluminação e extermínio, este riso do qual falamos agora é tido como uma 'ferramenta para a educação', conscientemente utilizado visando a mudanças de comportamento.

Em segundo lugar, em que medida deseja-se, realmente, promover "mudanças de comportamento"? E em que condições? Esta questão (que diz respeito à cidadania e ao sentido do que seja 'educar') não pode ser respondida aqui, por um motivo simples: é uma discussão que vem se dando em todos os níveis da relação governo/sociedade, Academia/serviços/ população, e que ainda está longe de ser solucionada. No que toca a este trabalho, podemos dizer que a proposição do "humor como instrumento da educação" é no mínimo inconsistente, já que, mesmo entre os que advogam tal possibilidade, ainda não se sabe como bem 'utilizá-lo' (considerando que isso seja possível), nem quando. Não se sabe nem ao menos o que utilizar, já que existem vários tipos, meios e qualidades de humor, e muitas formas de se trabalhar com o riso e o risível.

É impossível, de posse do que temos até aqui, responder a estas questões satisfatoriamente. Minha contribuição, quanto à utilização do humor como ferramenta de educação e prevenção, terá sido, por outro lado, levantar algumas questões relevantes:

1) É possível que haja uma 'apropriação' consciente e objetiva do humor como ferramenta, digamos, ideológica?

2) Caso seja possível (e necessária), em que medida e em que condições deve ela se dar? O humor aplica-se a toda e qualquer situação de comunicação, ou somente a algumas? Sendo assim, quais?

O diálogo entre Jorge de Burgos e Guilherme de Baskerville, em O nome da rosa, permanece vivo e atual, sob outra roupagem que não os hábitos monásticos. "Quem ri não acredita... nem tampouco odeia.” O riso não tem coração, como indica Bergson. A questão medieval hoje nos parece tola ("O riso é de Deus ou do diabo?"), mas se olharmos com bastante atenção veremos que em essência é a mesma. $\mathrm{O}$ riso é incentivo à dúvida, e a dúvida é potencialmente perigosa ao bom senso, ao senso comum, à 'normalidade', às tradições. O filósofo Charles Sanders Peirce (1975, p. 77) sugere que o homem que não duvida é como um avestruz que 
enterra a cabeça na areia ao menor sinal de perigo: simplesmente afasta o perigo de diante de seus olhos para assim crer que não há perigo algum. Diz Peirce que tal homem pode atravessar toda a existência sistematicamente afastando de diante de si tudo aquilo que poderia levá-lo a modificar suas opiniões. "O estímulo da dúvida é o único motivo imediato do esforço por chegar à crença”, diz ele, e com maior precisão: “a dúvida é um estado desagradável e incômodo, de que lutamos por libertar-nos e passar ao estado da crença; este é um estado de tranqüilidade e satisfação que não desejamos evitar ou transformar na crença de algo diverso. Pelo contrário, apegamo-nos tenazmente não apenas a crer, mas a crer no que cremos".

É fácil, pois, perceber que ambos, tanto o abade Jorge quanto o franciscano Guilherme concordam plenamente com a afirmação de que "o riso é incentivo à dúvida". E pela mesma razão compreendemos por que um deles diz intimamente "Maldito riso", enquanto o outro: "Bendito riso". Maravilhosamente, mais uma vez, ambos estão cobertos de razão.

\section{REFERÊENCIAS BIBLIOGRÁFICAS}

Alberti, Verena 1999

Andrade, Ricardo $\mathrm{J}$. 1998

Aristóteles 1987

Aristóteles

1956

Barbosa, Gustavo

Guimarães e Rabaça, Carlos Alberto 1998

Barthes, Roland 1984

Bergson, Henri 1983

Codo, Yara; Costa, Gualberto; Lovetro, José Alberto e Neto, Antonio (orgs.) 1998

Codo, Yara; Costa, Gualberto; Lovetro, José Alberto e Neto, Antonio (orgs.) 1997

Codo, Yara; Costa, Gualberto; Lovetro, José Alberto e Neto, Antonio (orgs.) 1997
O riso e o risivel na história do pensamento. Rio de Janeiro, Fundação Getúlio Vargas.

A significação do cômico no pensamento de Henri Bergson. Paper, UFRJ.

Poética. Trad. de Eudoro de Souza.

São Paulo, Nova Cultural.

Les parties des animaux.

Trad. de Pierre Louis. Paris, Les Belle Lettres.

Dicionário de comunicação.

São Paulo, Ática.

A câmara clara.

Rio de Janeiro, Nova Fronteira.

O riso: ensaio sobre a significação do cômico. Rio de Janeiro, Zahar.

Bienal Internacional de Humor - Catálogo. São Paulo, Jal \& Gual Comunicação.

Aids: o que é, quando se pega, onde se pega, como se evita. São Paulo, Jal \& Gual Comunicação.

Bienal Internacional de Humor - Revista Projeto. São Paulo, Jal \& Gual Comunicação. 


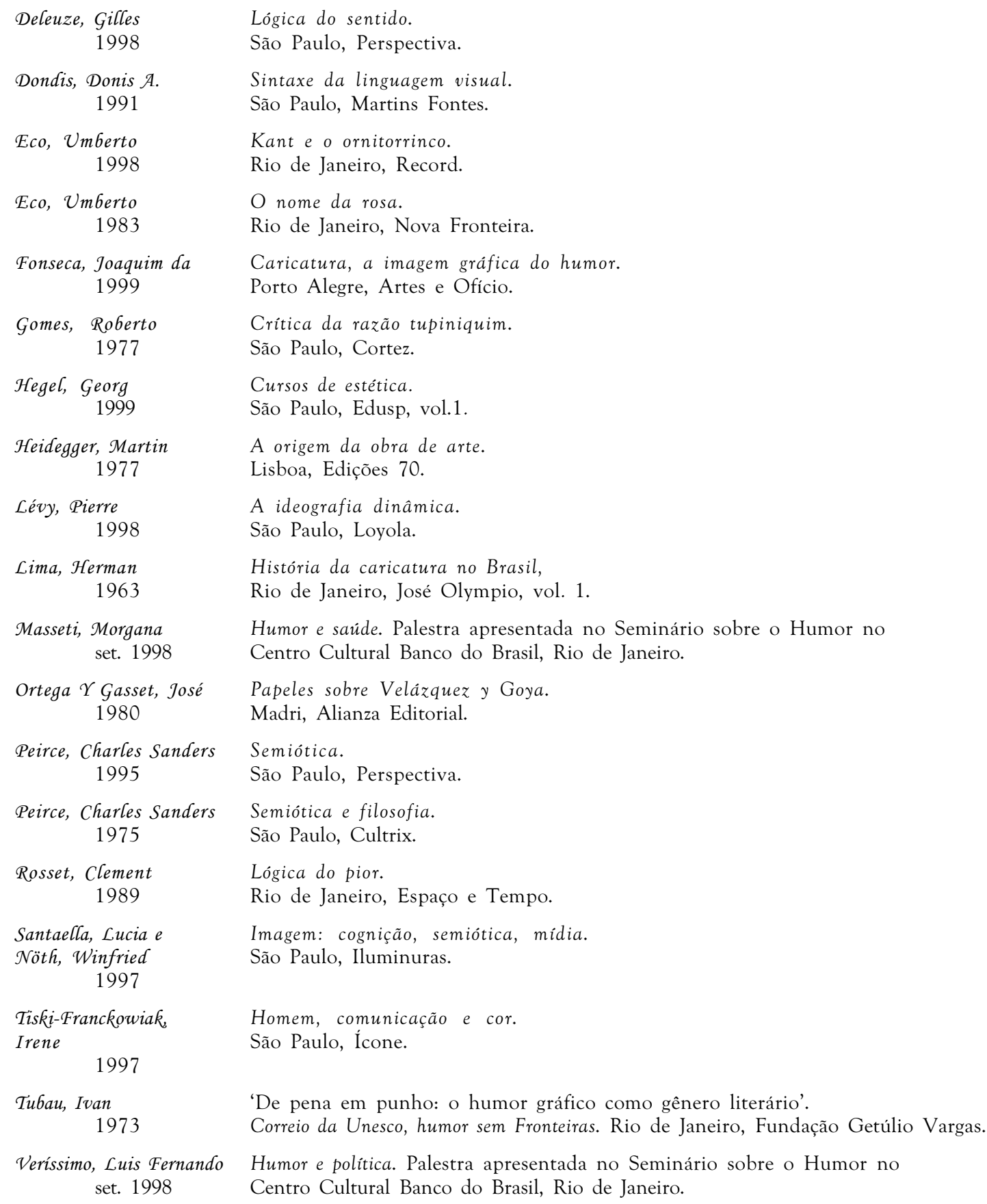

Agradecimentos especiais a José Alberto Lovetro (Jal), Gualberto Costa, Yara Codo e equipe da Estação das Artes, por facilitar o acesso ao material da bienal e pelo apoio e carinho e a Danielle Schlossarek, pelas valiosas sugestões e 'olho clínico'. 